USGS/WRIR--95-4035

\title{
SHALLOW INFILTRATION PROCESSES AT YUCCA MOUNTAIN, NEVADA- NEUTRON LOGGING DATA 1984-93
}

\section{U.S. GEOLOGICAL SURVEY}

Water-Resources Investigations Report 95-4035

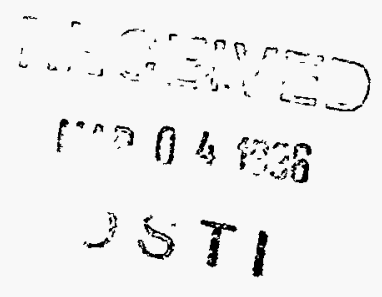

Prepared in cooperation with the NEVADA OPERATIONS OFFICE, U.S. DEPARTMENT OF ENERGY under Interagency Agreement DE-AI08-92NV10874

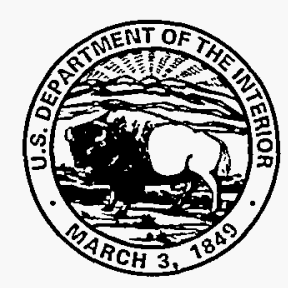




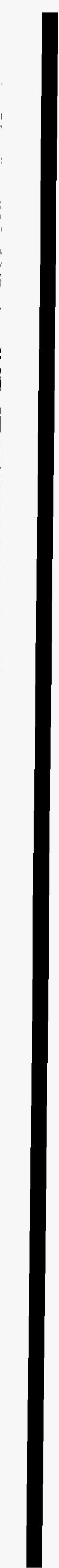




\section{SHALLOW INFILTRATION PROCESSES AT YUCCA MOUNTAIN, NEVADA- NEUTRON LOGGING DATA 1984-93}

by Lorraine E. Flint and Alan L. Flint

U.S. GEOLOGICAL SURVEY

Water-Resources Investigations Report 95-4035

Prepared in cooperation with the

NEVADA OPERATIONS OFFICE,

U.S. DEPARTMENT OF ENERGY under

Interagency Agreement DE-Al08-92NV10874

Denver, Colorado

1995

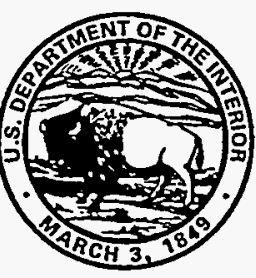




\title{
U.S. DEPARTMENT OF THE INTERIOR BRUCE BABBITT, Secretary
}

\author{
U.S. GEOLOGICAL SURVEY
}

Gordon P. Eaton, Director

\section{DISCLAIMER}

\begin{abstract}
This report was prepared as an account of work sponsored by an agency of the United States Government. Neither the United States Government nor any agency thereof, nor any of their employees, makes any warranty, express or implied, or assumes any legal liability or responsibility for the accuracy, completeness, or usefulness of any information, apparatus, product, or process disclosed, or represents that its use would not infringe privately owned rights. Reference herein to any specific commercial product, process, or service by trade name, trademark, manufacturer, or otherwise does not necessarily constitute or imply its endorsement, recommendation, or favoring by the United States Government or any agency thereof. The views and opinions of authors expressed herein do not necessarily state or reflect those of the United States Government or any agency thereof.
\end{abstract}

The use of trade, product, industry, or firm names is for descriptive purposes only and does not imply endorsement by the U.S. Government.

For additional information write to: Chief, Earth Science Investigations Program Yucca Mountain Project Branch U.S. Geological Survey Box 25046, MS 421 Denver Federal Center Denver, CO 80225
Copies of this report can be purchased from: U.S. Geological Survey Earth Science Information Center Open-File Reports Section Box 25286, MS 517

Denver Federal Center Denver, CO 80225 


\section{CONTENTS}

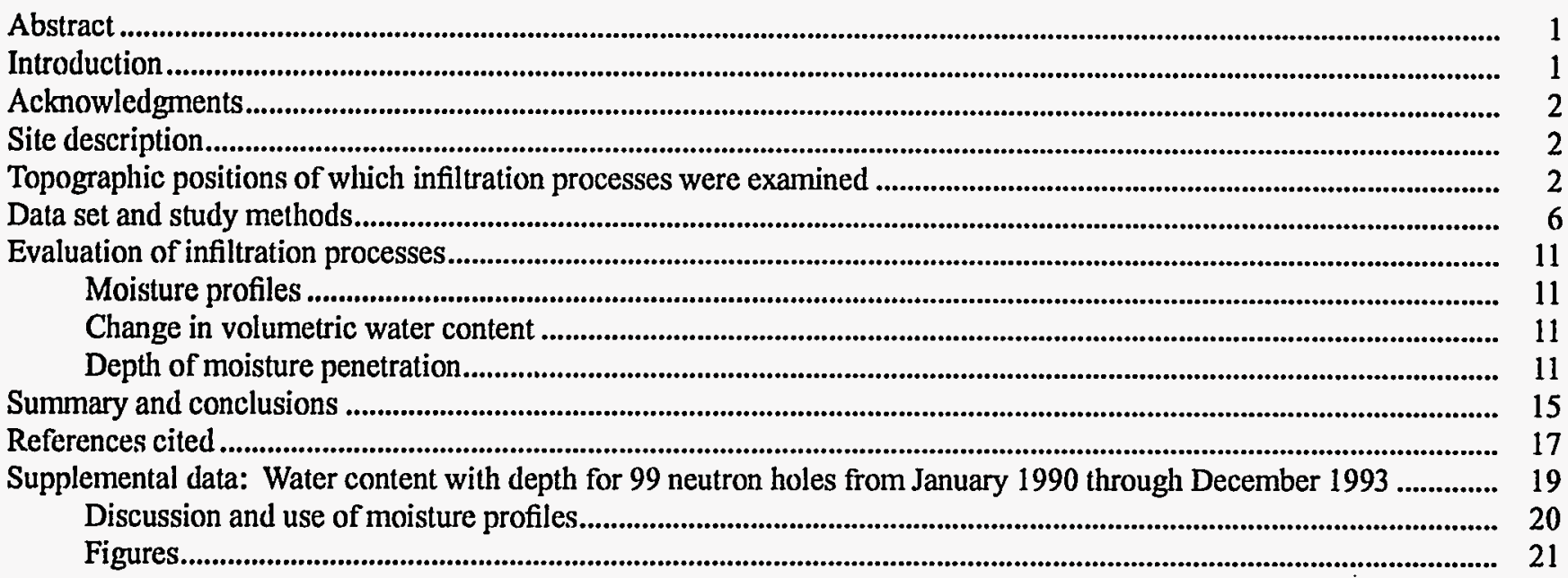

\section{FIGURES}

1. Map of study area with potential repository boundary and neutron hole locations ................................................ 3

2. Stratigraphic column for Yucca Mountain showing nomenclature ........................................................................... 4

3. Idealized representation of topographic positions: ridgetop, sideslope, terrace, and channel ................................ 5

4. Moisture profiles from boreholes at Yucca Mountain in each of the topographic positions from January 1990 through April 1993

5. Volumetric water content with depth for (a) terrace and (b) channel neutron holes at Yucca Mountain before and after runoff event, August 20,1984

6. Change in volumetric water content, in millimeters, for four depth intervals over a 3.3-year period at Yucca Mountain for boreholes from channel, sideslope, and ridgetop positions.

7. Depth-of-water content variation and depth of soil cover at Yucca Mountain for 34 boreholes .................................. 16

8-11. Volumetric water content with depth for boreholes UE-25 UZN \#1, UE-25 UZN \#2, UE-25 UZN \#3, and UE-25 UZN \#4 .

12-15. Volumetric water content with depth for boreholes UE-25 UZN \#5, UE-25 UZN \#6, UE-25 UZN \#7, and UE-25 UZN \#8 .

16-19. Volumetric water content with depth for boreholes UE-25 UZN \#9, UE-25 UZN \#10, USW UZ-N11, and UE-25 UZN \#12

20-23. Volumetric water content with depth for boreholes UE-25 UZN \#13, UE-25 UZN \#14, USW UZ-N15, and USW UZ-N16.

24-27. Volumetric water content with depth for boreholes USW UZ-N17, UE-25 UZN \#18, UE-25 UZN \#19, and UE-25 UZN \#20

28-31. Volumetric water content with depth for boreholes UE-25 UZN \#21, UE-25 UZN \#22, UE-25 UZN \#23, and USW UZ-N24.

32-35. Volumetric water content with depth-for boreholes USW UZ-N25, USW UZ-26, USW UZ-N27, and UE-25 UZN \#28

36-39. Volumetric water content with depth for boreholes UE-25 UZN \#29, UE-25 UZN \#30, USW UZ-N31, and USW UZ-N32.

40-43. Volumetric water content with depth for boreholes USW UZ-N33, USW UZ-N34, USW UZ-N35, and USW UZ-N36.

44-47. Volumetric water content with depth for boreholes USW UZ-N37, USW UZ-N38, UE-25 UZN \#39, and USW UZ-N40.

48-51. Volumetric water content with depth for boreholes USW UZ-N41, USW UZ-N42, USW UZ-N43, and USW UZ-N44.

52-55. Volumetric water content with depth for boreholes USW UZ-N45, USW UZ-N46, USW UZ-N47, and USW UZ-N48.

56-59. Volumetric water content with depth for boreholes USW UZ-N49, USW UZ-N50, USW UZ-N51, and USW UZ-N52. 
60-63. Volumetric water content with depth for boreholes USW UZ-N53, USW UZ-N54, USW UZ-N55, and UE-25 UZN \#56

64-67. Volumetric water content with depth for boreholes USW UZ-N57, USW UZ-N58, USW UZ-N59, and UE-25 UZN \#60

68-71. Volumetric water content with depth for boreholes USW UZ-N61, USW UZ-N62, UE-25 UZN \#63, and USW UZ-N64

72-75. Volumetric water content with depth for boreholes USW UZ-N65, USW UZ-N66, USW UZ-N67, and USW UZ-N68.

76-79. Volumetric water content with depth for boreholes USW UZ-N69, USW UZ-N70, USW UZ-N71, and USW UZ-N72

80-83. Volumetric water content with depth for boreholes USW UZ-N73, USW UZ-N74, USW UZ-N75, and USW UZ-N76.

84-87. Volumetric water content with depth for boreholes USW UZ-N77, USW UZ-N78, USW UZ-N79, and USW UZ-N80.

88-91. Volumetric water content with depth for boreholes USW UZ-N81, USW UZ-N82, USW UZ-N83, and USW UZ-N84.

92-95. Volumetric water content with depth for boreholes UE-25 UZN \#85, USW UZ-N86, USW UZ-N87, and USW UZ-N88

96-99. Volumetric water content with depth for boreholes USW UZ-N89, USW UZ-N90, UE-25 UZN \#91, and UE-25 UZN \#92

100-103. Volumetric water content with depth for boreholes USW UZ-N93, USW UZ-N94, USW UZ-N95, and USW UZ-N96

104-106. Volumetric water content with depth for boreholes USW UZ-N97, USW UZ-N98, and USW UZ-7

\section{TABLES}

1. Calibration equations for all neutron moisture meters used from May 1984 through December 1993

2. List of boreholes, location and altitude, drilling dates, description, depths, and lithology at Yucca Mountain

3. Mean and standard deviation for the depth of alluvium and estimated depth of penetration of seasonal infiltrating water in all boreholes, except in N91 and N92, in channels, terraces, sideslopes and ridgetops, at Yucca Mountain, Nevada

\section{CONVERSION FACTORS}

Multiply

cubic centimeter $\left(\mathrm{cm}^{3}\right)$

kilometer $(\mathrm{km})$

meter $(\mathrm{m})$

millimeter $(\mathrm{mm})$

$3.531 \times 10^{-5}$
0.6214
3.281
0.03937

cubic foot $\left(\mathrm{ft}^{3}\right)$

mile (mi)

foot (ft)

inch (in) 


\title{
Shallow Infiltration Processes at Yucca Mountain, Nevada- Neutron Logging Data 1984-93
}

\author{
By Lorraine E. Flint and Alan L. Flint
}

\section{Abstract}

To determine site suitability of Yucca Mountain, Nevada, as a potential high-level radioactive waste repository, a study was devised to characterize net infiltration. This study involves a detailed data set produced from 99 neutron boreholes that consisted of volumetric water-content readings with depth from 1984 through 1993 at Yucca Mountain. Boreholes were drilled with minimal disturbance to the surrounding soil or rock in order to best represent field conditions. Boreholes were located in topographic positions representing infiltration zones identified as ridgetops, sideslopes, terraces, and active channels. Through careful field calibration, neutron moisture logs, collected on a monthly basis and representing most of the areal locations at Yucca Mountain, illustrated that the depth of penetration of seasonal moisture, important for escaping loss to evapotranspiration, was influenced by several factors. It was increased (1) by thin soil cover, especially in locations where thin soil is underlain by fractured bedrock; (2) on ridgetops; and (3) during the winter when evapotranspiration is low and runoff is less frequent. This data set helps to provide a seasonal and areal distribution of . changes in volumetric water content with which to assess hydrologic processes contributing to net infiltration.

\section{INTRODUCTION}

Net infiltration, that component of precipitation that percolates downward beyond the influences of evapotranspiration (ET) to recharge the ground-water system, is an important boundary condition for hydrologic flow models designed to calculate flux through the thick unsaturated zone at Yucca Mountain (Winograd and Thordarson, 1975). Determining net infiltration in arid lands often becomes a qualitative endeavor of characterizing processes and mechanisms, as there are many errors associated with measuring or estimating upward and downward flux (De Bruin, 1988; Dreiss and Anderson, 1985). For example, low rainfall results in measurement and mass-balance calculation errors; heterogeneous, rocky, and shallow surficial material (soil) also makes it difficult to determine values of infiltration in arid lands. One way to approach the characterization of infiltration is through a systematic monitoring program to measure volumetric water content in boreholes. A data set has been developed consisting of volumetric water-content readings in 99 neutron-access boreholes (neutron holes) monitored from 1984 (or when they were drilled) through 1993. The preliminary analysis of this data set has contributed to an understanding of the mechanisms and processes by which precipitation becomes net infiltration in a variety of topographic locations and surface materials. The purpose of this report is to provide data users with preliminary interpretations and descriptions of the environment and methodologies under which the data were collected.

The depth of infiltration of water into the soil/ rock profile fluctuates on a seasonal basis, but estimates can be made of long-term trends, and an average depth of penetration can be established (Flint and others, 1994). Examination of borehole core samples and surface excavations has indicated that most of the fractures in the shallow soil or bedrock are filled with calcium carbonate minerals precipitated as a result of repeated wetting and drying. This fracture filling occurs to varying depths in different locations but commonly ranges from about 3 to $15 \mathrm{~m}$. The depth of seasonal water pulses, observed by geophysical logging of a network of boreholes, corresponds approximately to the depth of the calcium carbonate materials, which identifies a conceptual zone of evapotranspiration and a depth beyond which net infiltration is likely to occur.

The presence of fractures affects, and usually increases, the penetration of water into the profile because of an increase in storage capacity, which is due to more porous fracture fill, open fractures at the surface, or open fractures at depth. Theoretically, 
under unsaturated conditions, fracture flow will not be initiated if the surrounding matrix has smaller pores than the aperture of the unfilled fractures, and the matrix must be nearly saturated to initiate fracture flow. However, if pulses of water do flow into fractures, the much higher conductivity of the fractures, along with the smaller volume, will conduct the water to greater depths.

This paper addresses the mechanics involved in collecting this large data set, as well as the caveats associated with the data. Preliminary interpretations provide insights into mechanisms and processes of shallow infiltration at Yucca Mountain.

\section{ACKNOWLEDGMENTS}

The authors would like to acknowledge many people who contributed to the collection, organization, and understanding of the neutron borehole data set. The data were collected over the period of time from 1984 through 1993 by 49 people working for the U.S. Geological Survey, Fenix and Scisson, Raytheon Services Nevada, Goodson and Associates, Foothill Engineering Consultants, and Colorado School of Mines. Early contributors to the selection of borehole sites, drilling coordination, and data collection procedures are Dale Hammermeister, Dan Blout, and Bill Davies. Major contributors to the development and organization of the data base are David Hudson, Joe Gonzales, and Kevin Ellett. John Klenke, Kevin Ellett, and David Hudson helped to develop the procedure and equations for field calibrating the neutron moisture meters. Joe Hevesi is acknowledged for his analysis of borehole data through numerical modeling to gain insight into the mechanisms of shallow infiltration, and Maliha Nash helped to review the final data set and produce the figures for the supplemental data section of this paper.

\section{SITE DESCRIPTION}

Yucca Mountain is in the northern Mojave Desert in southern Nevada (fig. 1). It is a faulted ridge consisting of a series of layered, nonwelded and welded, variably fractured and saturated pyroclastic rocks (fig. 2). The topography of the mountain has been defined by erosional processes on the eastern sloping ridge and along faults and fault scarps that have created a series of washes that are downcut to varying degrees into different bedrock layers. The washes are primarily east-west and northwest trending, with gentle to steep slopes, and have available energy loads that vary greatly for much of the year. The bedrock exposed at the surface or directly underlying alluvial cover ranges from nonwelded, unfractured rock that has 40-percent porosity, to densely welded, highly fractured rock that has less than 10-percent porosity. The alluvial/colluvial surficial deposits have varying degrees of soil development and thickness and have a gravelly texture; rock fragments (greater than $2 \mathrm{~mm}$ ) constitute between 20 and 80 percent of the total volume. More stable surfaces, generally on the flat upland ridges, have higher clay contents. Deeper soils in the center of many washes have developed cemented calcium carbonate layers. In this report, all unconsolidated surficial materials will be referred to as soil. Because of the high variability and range of properties and surface features, descriptions are qualitative in terms of slope, aspect, and depth. General descriptions are for the purpose of identifying processes and mechanisms of surface and subsurface flow in relatively distinctive topographic positions, but they necessarily overlap in areas.

Average annual precipitation at the site is about $170 \mathrm{~mm}$ (Hevesi and others, 1992). Precipitation occurs as localized thunderstorms in the summer when the evapotranspiration (ET) demand is very high. Most of the water is lost to ET processes within several days, unless there is enough rainfall to produce runoff or if subsequent storms provide additional water for deeper penetration. Thunderstorms in the area can create runoff in one wash while an adjacent wash receives no rain at all. Precipitation in the winter occurs in large stratiform storm patterns as snow or rain. ET is low at this time of year, and lower precipitation rates or slowly melting snow may penetrate deeper into the soil profile.

\section{TOPOGRAPHIC POSITIONS OF WHICH INFILTRATION PROCESSES WERE EXAMINED}

In this study, infiltration processes and mechanisms are examined for four topographic positionsridgetop, sideslope, terrace, and channel (fig. 3). Over an area within the boundaries of the site-scale model (Wittwer and others, 1992), the ridgetop locations encompass about 14 percent of the total area, the sideslopes 62 percent, the terraces 22 percent, and the active channels 2 percent. The ridgetop locations are generally flat to gently sloping and are higher in altitude than the other areas. They have relatively thin to no surficial deposits but are relatively stable morphologically. Existing soils are fairly well developed, and thin calcium carbonate layers are fairly common. Some perennial channels have somewhat thicker soils, and some concentrated surface runoff occurs. Bedrock at ridgetop locations is moderately to densely welded ( 5 to 25 percent porosity) and moderately to highly fractured. Vegetation consists of well-established, rel- 


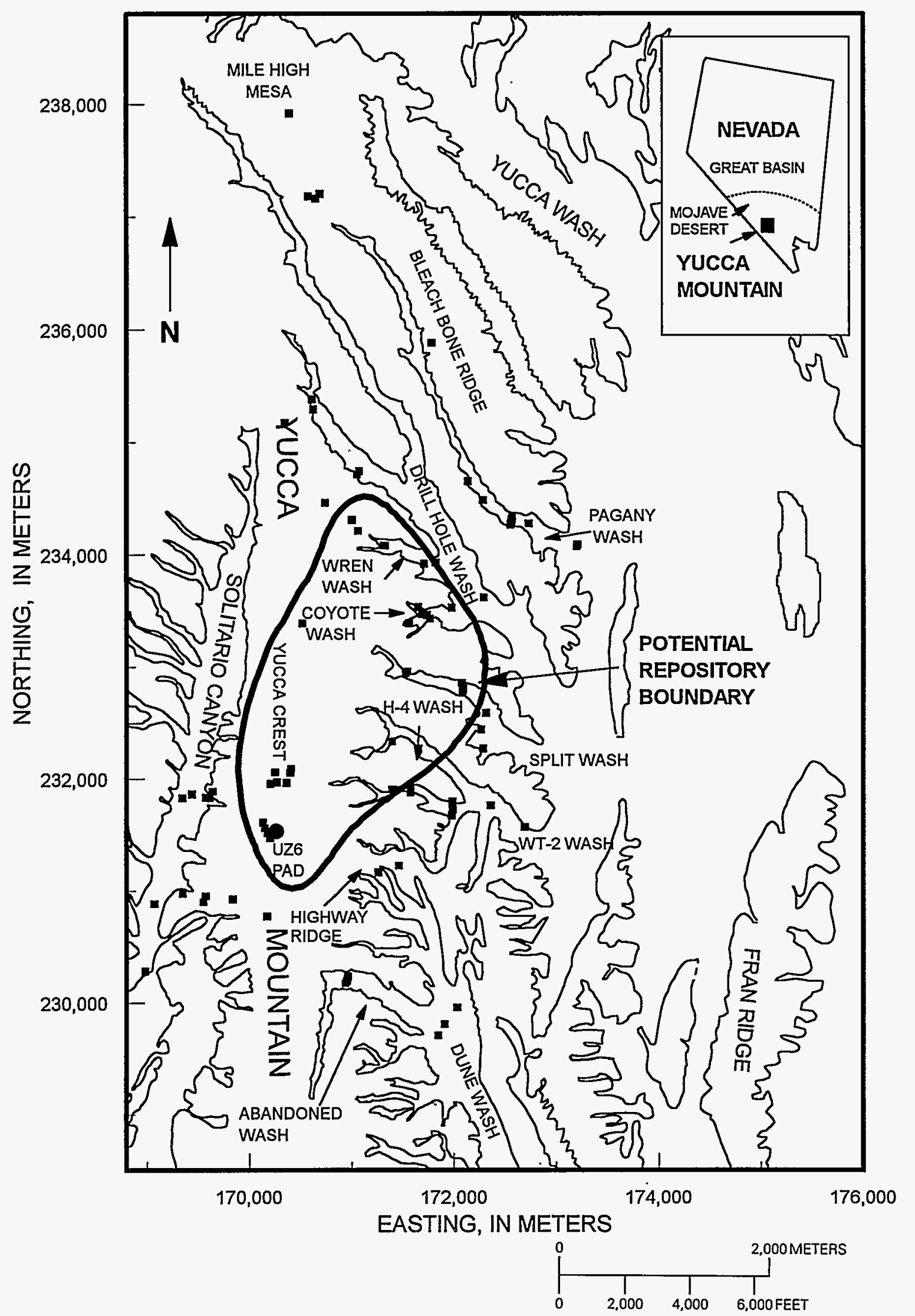

Figure 1. Map of study area with potential repository boundary and neutron hole locations. Contours indicate bedrock/alluvium boundary according to Scott and Bonk (1984). 


\begin{tabular}{|c|c|c|}
\hline \multicolumn{2}{|c|}{$\begin{array}{l}\text { Stratigraphic Nomenclature } \\
\text { Sawyer and others, } 1994\end{array}$} & $\begin{array}{l}\text { Stratigraphic Nomen- } \\
\text { clature modified from } \\
\text { Scott and Bonk, } 1984\end{array}$ \\
\hline \multirow{19}{*}{ 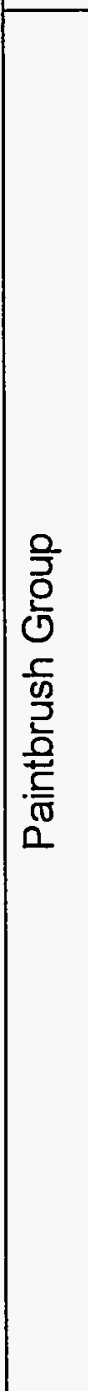 } & \multirow{8}{*}{$\begin{array}{l}\text { Tiva } \\
\text { Canyon } \\
\text { Tuff }\end{array}$} & ccr - caprock \\
\hline & & cuc - upper cliff \\
\hline & & cul - upper lithophysal \\
\hline & & cks - clinkstone \\
\hline & & cll - lower lithophysal \\
\hline & & ch - hackly \\
\hline & & cc - columnar \\
\hline & & ccs - shardy base \\
\hline & Yucca Mountain Tuff & \\
\hline & Pah Canyon Tuff & \\
\hline & \multirow{9}{*}{$\begin{array}{l}\text { Topopah } \\
\text { Spring } \\
\text { Tuff }\end{array}$} & tn- upper nonwelded \\
\hline & & tc - caprock \\
\hline & & tr - rounded \\
\hline & & tul - upper lithophysal \\
\hline & & tnl - nonlithophysal \\
\hline & & tIl - lower lithophysal \\
\hline & & tm - mottled \\
\hline & & tv- basal vitrophyre \\
\hline & & nonwelded base \\
\hline \multicolumn{2}{|c|}{ Calico Hills Formation } & Tht - zeolitized \\
\hline 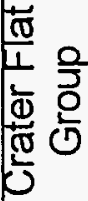 & $\begin{array}{l}\text { Prow } \\
\text { Pass } \\
\text { Tuff }\end{array}$ & pp - prow pass tuff \\
\hline
\end{tabular}

Figure 2. Stratigraphic column for Yucca Mountain showing nomenclature (Sawyer and others, 1994; and Scott and Bonk, 1984). 


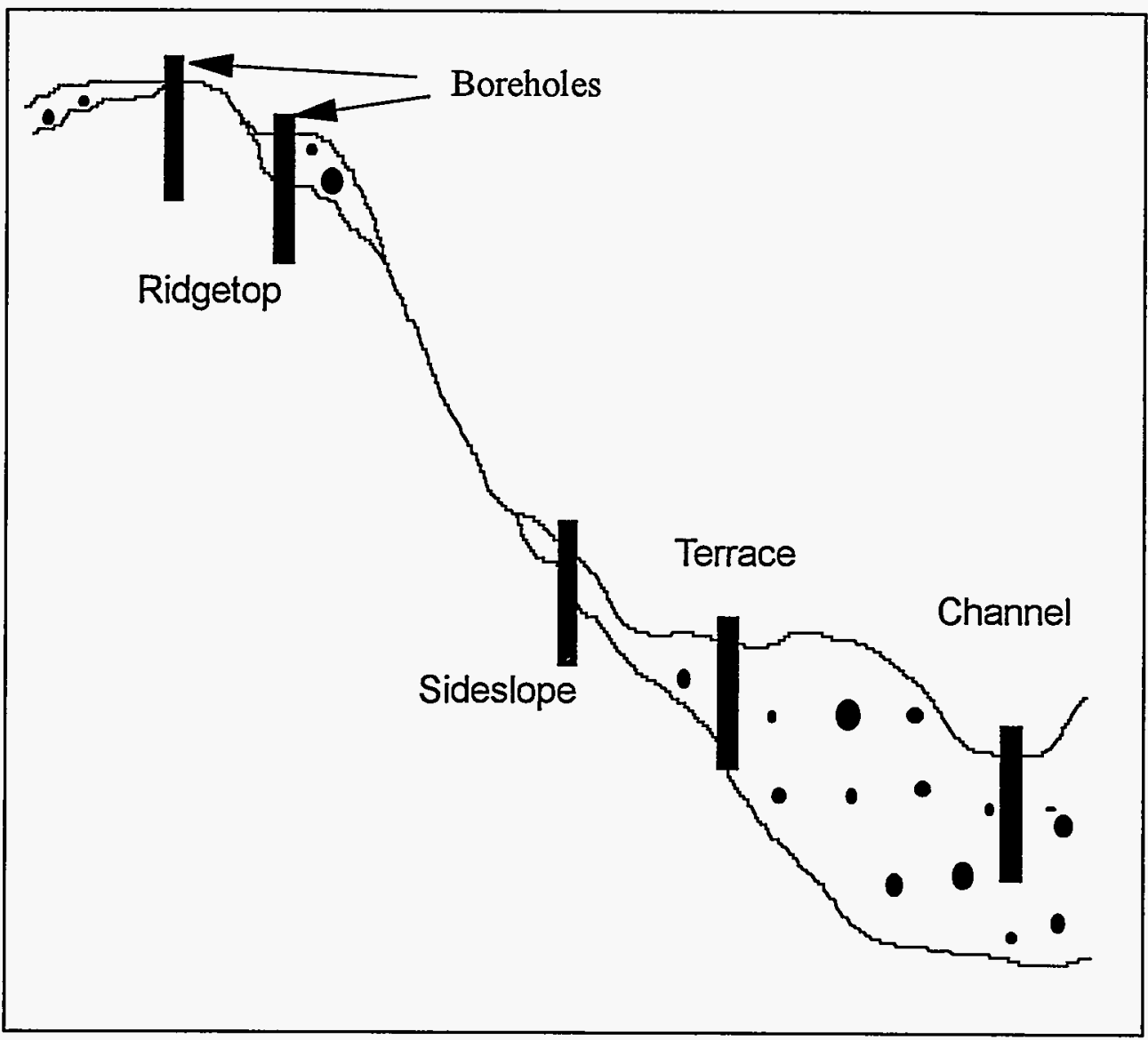

Figure 3. Idealized representation of topographic positions: ridgetop, sideslope, terrace, and channel. 
atively shallow-rooted, blackbrush/desert thorn associations (O'Farrell and Collins, 1983). The slope and elevation in this position tend to retain snowfall in the winter for several weeks at a time.

Because of the difficulty of drilling boreholes at steep sideslope locations, field data for this position are limited to sites on the lower sideslopes of washes. This location is distinguished from the terrace and channel locations by depth of soils and slope. Soil cover is thin to nonexistent, and in most locations, bedrock is densely welded and highly fractured. The side slopes are approximately north or south facing and, therefore, have different seasonal solar radiation loads. In some locations, side channels concentrate runoff water. In general, sideslopes tend to be more sparsely vegetated than the other topographic positions.

Terraces and channels are located at lower elevations in the main washes and have thin soil cover in the upper washes and thick soils farther down. A very small percentage of exposed bedrock exists in the washes, and almost all of that is nonwelded, highly porous tuff. The soil has varying degrees of calciumcarbonate cementation, that commonly is quite extensive. The porosity of the soil ranges from 15 to 50 percent. The surface is relatively flat and dissected by old alluvial channels and active channels. Channels are distinguished from terraces by periodic runoff in the channels under extreme precipitation conditions. The terraces generally are well vegetated, having deeply rooted creosote and other smaller plants. The channels occupy a very small surface area of the wash and are more sparsely vegetated than the terraces.

\section{DATA SET AND STUDY METHODS}

Boreholes were drilled using dry-drilling technology and the ODEX 115 drilling and casing system (Hammermeister and others, 1985). This method uses simultaneous advancement of the casing with the deepening of the hole to minimize the effects of drilling medium (in this case, air) on the borehole walls. The steel casing used for the Yucca Mountain boreholes has a $130-\mathrm{mm}$ inside diameter. Formation-volumetric water content is minimally disturbed, and some of the cuttings produced from drilling fill the small annular spaces between the casing and formation, minimizing the void space. This type of drilling also provided continuous core sampling of the last 24 boreholes drilled. These samples were used to measure field-volumetric water contents in different types of lithologies in order to develop field calibration equations.

Volumetric water-content profiles were measured in the boreholes using neutron moisture meters (Model 503, Campbell Pacific Nuclear, Pacheco,
Calif.), with an ${ }^{241} \mathrm{Am}-\mathrm{Be}, 50 \mathrm{mCi}$ source and ${ }^{3} \mathrm{He}$ detector. This meter detects an area surrounding the probe of approximately $0.7-\mathrm{m}$ vertically and $175-\mathrm{mm}$ radius horizontally (Klenke and Flint, 1991). Despite the unconventional casing for neutron logging, which commonly uses $50-\mathrm{mm}$ inside diameter casing (Tyler, 1986), the neutron probes were successfully calibrated using field samples collected during the drilling of several boreholes. The calibration holes were drilled through alluvium, welded and nonwelded tuff with samples collected every $0.7 \mathrm{~m}$ and preserved onsite to maintain field moisture conditions. These samples were then processed in the lab to determine volumetric water content. The calibration equations were developed relating neutron counts from the boreholes linearly to volumetric water content of the samples (table 1). Five tanks were constructed to maintain known water conditions. They are $1.5 \mathrm{~m}$ in diameter and provide a continuous measurement medium (Klenke and Flint, 1991). These tanks were used to assess long-term drift of the meters so that corrections of neutron decay could be made over time. They also were used to develop transfer equations for meters that were not used to measure field moisture conditions at the time the samples were collected for field calibration.

The first phase of borehole drilling was between May 15, 1984, and February 26, 1986, when 74 neutron holes were drilled, extending in depth from $4.6 \mathrm{~m}$ to $30 \mathrm{~m}$, with one borehole extended to $36.6 \mathrm{~m}$ to reach the water table in upper Fortymile Canyon, $22 \mathrm{~km}$ north of Yucca Mountain. An additional borehole, USW UZ-7, was drilled to $63.1 \mathrm{~m}$, but the casing was pulled back up to $6.7 \mathrm{~m}$. The primary consideration for borehole location was spatial distribution over the mountain with an emphasis on the washes. Boreholes in the washes penetrated through the entire alluvial thickness and extended about $1 \mathrm{~m}$ into the underlying tuff. This distribution of boreholes provided excellent coverage of many of the washes in the form of cross sections of the channels, with many boreholes fairly closely spaced. Drilling was halted from March 1986 to September 1991.

The second phase of drilling included 24 additional boreholes. These boreholes were located to emphasize an improved coverage of topographic positions, especially sideslope and ridgetop positions to the north of the potential repository location, as well as providing deeper penetration, from 18.3 to $78 \mathrm{~m}$. Boreholes were located to penetrate through and collect core samples from the nonwelded Paintbrush Group and into the densely welded vitric caprock of the Topopah Spring Tuff (fig. 2). One series of boreholes (USW UZN-57, USW UZN-58, USW UZN-59, and 
Table 1. Calibration equations for all neutron moisture meters used from May 1984 through December 1993

\begin{tabular}{cl}
\hline Meter & Callbration equation \\
\hline 0 & Volumetric water content $=5.316 \times 10^{-5} *$ counts $-7.074 \times 10^{-2}$ \\
1 & Volumetric water content $=4.362 \times 10^{-5} *$ counts $-8.015 \times 10^{-2}$ \\
2 & Volumetric water content $=5.143 \times 10^{-5} *$ counts $-6.819 \times 10^{-2}$ \\
3 & Volumetric water content $=5.128 \times 10^{-5} *$ counts $-7.314 \times 10^{-2}$ \\
4 & Volumetric water content $=7.935 \times 10^{-5} *$ counts $-7.159 \times 10^{-2}$ \\
5 & Volumetric water content $=8.301 \times 10^{-5} *$ counts $-7.086 \times 10^{-2}$ \\
6 & Volumetric water content $=5.333 \times 10^{-5} *$ counts $-6.551 \times 10^{-2}$ \\
7 & Volumetric water content $=7.484 \times 10^{-5} *$ counts $-7.623 \times 10^{-2}$ \\
8 & Volumetric water content $=8.242 \times 10^{-5} *$ counts $-7.665 \times 10^{-2}$ \\
9 & Volumetric water content $=7.590 \times 10^{-5} *$ counts $-7.053 \times 10^{-2}$ \\
\hline
\end{tabular}

USW UZN-61) extended across a wash and was drilled directly into the caprock of the Topopah Spring Tuff, which was poorly represented in the boreholes drilled in the first phase. One borehole was drilled into the Ghost Dance fault (USW UZN-35), reaching fault breccia at approximately $34 \mathrm{~m}$. Boreholes were continuously cored and samples were preserved for laboratory measurement approximately every $0.8 \mathrm{~m}$. Three boreholes (USW UZN-55, USW UZN-54, and USW UZN-27) were used to provide field volumetric water contents for calibration of the neutron moisture meters. A list of all boreholes, drilling dates, borehole and casing depths, and a description of each borehole is included in table 2 . Official borehole designations are listed in table 2 but will be referred to in the text by the letter "N" and corresponding borehole number 1 through 98. The additional borehole, USW UZ-7, not designated as a neutron borehole, is referred to as UZ-7. Locations of all boreholes are plotted on figure 1, except for N91 and N92, which are located about $25 \mathrm{~km}$ north of Yucca Mountain, N39, which is located in Jackass Flats about $25 \mathrm{~km}$ east of Yucca Mountain, and N85, which is located on the western edge of Fortymile Wash just east of Fran Ridge.

With some exceptions, the data were collected on a monthly basis. Boreholes deeper than $30 \mathrm{~m}$ are only logged to $19.4 \mathrm{~m}$ monthly, and to total depth on a 6-month basis. The upper $5 \mathrm{~m}$ of each borehole are logged at $0.1-\mathrm{m}$-depth intervals, and the remaining depth is logged at $0.3-\mathrm{m}$ intervals.

The period for data reported in this study extended from July 1984, when the boreholes were first logged, to December 1993, and had varying climatic conditions. Several runoff-producing storms were recorded in 1984, but the following 4 years, 1985-89, experienced drought conditions that averaged about
50 to 75 percent less than normal rainfall, which is 130 to $180 \mathrm{~mm} / \mathrm{yr}$. This resulted in gradual declines in the volumetric water contents of the shallow subsurface. By 1990, the volumetric water content in the boreholes had stabilized at between 2 and 5 percent, the lowest measured volumetric water content recorded since the boreholes were drilled. There was some relief from the drought in 1990, and precipitation during the winters of 1991-92 and 1992-93 was well above normal (total rainfall of 280 and $370 \mathrm{~mm}$, respectively). Several storms produced runoff in 1990-93.

Examples of moisture logs are presented, as well as changes in water content with depth over time. To evaluate these changes in the various boreholes and to identify ongoing processes contributing to net infiltration relative to the four topographic locations, moisture profiles at selected sites were analyzed in several ways. Profiles of volumetric water content were compared to assess the change in the water-content volume and depth of penetration (maximum depth of water-content change) over a winter season. The average change in volumetric water content is presented in figure 6 for depth intervals of 0.3 to $1 \mathrm{~m}, 1$ to $2 \mathrm{~m}, 2$ to $5 \mathrm{~m}$, and 5 to $10 \mathrm{~m}$ during a 3.3-year period. The change in volumetric water content of the upper $1 \mathrm{~m}$ of tuff over a single season was compared to overlying alluvial depth. Finally, the depth of penetration of seasonal pulses of water was assessed by estimating the depth at which changes of volumetric water content over time were minimal. This depth is compared to the topographic position of boreholes to assess the influence of borehole position on the depth of moisture penetration and, potentially, net infiltration. 
- Table 2. List of boreholes, location and altitude, drilling dates, description, depths, and lithology at Yucca Mountain

[Lithologies are described in figure 2; Tmr is Rainier Mesa Tuff; Qal is quaternary alluvium]

\begin{tabular}{|c|c|c|c|c|c|c|c|c|c|c|c|c|}
\hline $\begin{array}{l}\text { Borehole } \\
\text { designation }\end{array}$ & Location & $\begin{array}{l}\text { Northing } \\
\text { (meters) }\end{array}$ & $\begin{array}{c}\text { Easting } \\
\text { (meters) }\end{array}$ & $\begin{array}{l}\text { Altitude } \\
\text { (meters) }\end{array}$ & $\begin{array}{c}\text { Date } \\
\text { drilling } \\
\text { begun }\end{array}$ & $\begin{array}{l}\text { Date } \\
\text { drilling } \\
\text { com- } \\
\text { pleted }\end{array}$ & Topographlc position & $\begin{array}{l}\text { Infiltra- } \\
\text { tion zone }\end{array}$ & $\begin{array}{c}\text { Total } \\
\text { depth } \\
\text { (meters) }\end{array}$ & $\begin{array}{l}\text { Depth } \\
\text { of } \\
\text { casing } \\
\text { (meters) }\end{array}$ & $\begin{array}{l}\text { Depth } \\
\text { to } \\
\text { bedrock } \\
\text { (meters) }\end{array}$ & $\begin{array}{l}\text { Wthol- } \\
\text { ogy } \\
\text { of } \\
\text { upper- } \\
\text { most } \\
\text { bed- } \\
\text { rock }\end{array}$ \\
\hline UE-25 UZN \#1 & Pagany Wash & 234491 & 172280 & 1218 & $10 / 17 / 84$ & $10 / 18 / 84$ & Large channel bottom & Channel & 15.2 & 15.2 & 8.3 & $\overline{B T}$ \\
\hline UE-25 UZN \#2 & Pagany Wash & 234271 & 172552 & 1203 & $06 / 11 / 84$ & $06 / 14 / 84$ & Canyon wall & Sideslope & 15.2 & 15.2 & 0.0 & $\mathrm{ch}$ \\
\hline UE-25 UZN \#3 & Pagany Wash & 234278 & 172553 & 1201 & $06 / 15 / 84$ & $06 / 15 / 84$ & Terrace & Terrace & 4.6 & 4.6 & 2.7 & $\mathrm{ch}$ \\
\hline UE-25 UZN \#4 & Pagany Wash & 234288 & 172556 & 1202 & $06 / 15 / 84$ & $06 / 15 / 84$ & Terrace & Terrace & 9.1 & 9.1 & 7.5 & ch \\
\hline UE-25 UZN \#5 & Pagany Wash & 234296 & 172558 & 1202 & $06 / 18 / 84$ & $06 / 21 / 84$ & Terrace & Terrace & 15.2 & 15.2 & 13.6 & cc \\
\hline UE-25 UZN \#6 & Pagany Wash & 234302 & 172559 & 1200 & $06 / 21 / 84$ & $06 / 22 / 84$ & Large channel bottom & Channel & 13.7 & 13.7 & 1.0 & $\mathrm{cc}$ \\
\hline UE-25 UZN \#7 & Pagany Wash & 234307 & 172560 & 1201 & $07 / 13 / 84$ & $07 / 16 / 84$ & Large channel bottom & Channel & 13.7 & 13.7 & 12.3 & cc \\
\hline UE-25 UZN \#8 & Pagany Wash & 234313 & 172562 & 1201 & $07 / 16 / 84$ & $07 / 17 / 84$ & Large channel bottom & Channel & 13.7 & 13.7 & 12.2 & cc \\
\hline UE-25 UZN \#9 & Pagany Wash & 234325 & 172564 & 1201 & $07 / 17 / 84$ & $07 / 18 / 84$ & Terrace & Terrace & 12.2 & 12.2 & 10.7 & $\mathrm{cc}$ \\
\hline UE-25 UZN \#10 & Pagany Wash & 234656 & 172134 & 1231 & $12 / 02 / 85$ & $12 / 04 / 85$ & Large channel bottom & Channel & 30.2 & 28.7 & 0.0 & $\operatorname{ccs}$ \\
\hline USW UZ-N11 & Mile High Mesa & 237919 & 170390 & 1592 & $02 / 05 / 92$ & $02 / 25 / 92$ & Ridge & Ridgetop & 25.7 & 25.5 & 1.2 & $\mathrm{cc}$ \\
\hline UE-25 UZN \#12 & Pagany Wash & 234285 & 172729 & 1191 & $07 / 23 / 84$ & $07 / 24 / 84$ & Large channel bottom & Channel & 15.2 & 15.2 & 13.7 & $\mathrm{ch}$ \\
\hline UE-25 UZN \#13 & Pagany Wash & 234094 & 173204 & 1165 & $07 / 18 / 84$ & $07 / 19 / 84$ & Large channel bottom & Channel & 19.8 & 19.8 & 13.4 & Tmr \\
\hline UE-25 UZN \#14 & Pagany Wash & 234076 & 173197 & 1166 & $07 / 20 / 84$ & $07 / 23 / 84$ & Terrace & Terrace & 16.8 & 16.8 & 13.4 & Tmr \\
\hline USW UZ-N15 & Bleach Bone Ridge & 237162 & 170643 & 1557 & $03 / 20 / 92$ & $03 / 25 / 92$ & Small channel bottom & Ridgetop & 18.3 & 16.8 & 0.7 & $\operatorname{ccr}$ \\
\hline USW UZ-N16 & Bleach Bone Ridge & 237180 & 170574 & 1560 & $03 / 25 / 92$ & $03 / 30 / 92$ & Terrace & Ridgetop & 18.3 & 18.1 & 1.5 & cuc \\
\hline USW UZ-N17 & Bleach Bone Ridge & 237203 & 170687 & 1563 & $03 / 17 / 92$ & $03 / 19 / 92$ & Ridge & Ridgetop & 18.3 & 18.2 & 0.8 & ccr \\
\hline UE-25 UZN \#18 & Drill Hole Wash & 233621 & 172287 & 1225 & $05 / 16 / 84$ & $05 / 18 / 84$ & Large channel bottom & Channel & 18.6 & 18.6 & 17.0 & $\mathrm{ch}$ \\
\hline UE-25 UZN \#19 & Split Wash & 232772 & 172081 & 1227 & $11 / 06 / 85$ & $11 / 08 / 85$ & Large channel bottom & Channel & 12.2 & 12.2 & 6.9 & cc \\
\hline UE-25 UZN \#20 & Split Wash & 232794 & 172084 & 1227 & $05 / 15 / 84$ & $05 / 16 / 84$ & Braided channel area & Channel & 12.5 & 12.5 & 11.9 & ch \\
\hline UE-25 UZN \#21 & Split Wash & 232808 & 172087 & 1228 & $11 / 08 / 85$ & $11 / 14 / 85$ & Braided channel area & Channel & 12.8 & 12.8 & 8.4 & $\mathrm{ch}$ \\
\hline UE-25 UZN \#22 & Split Wash & 232831 & 172092 & 1228 & $11 / 14 / 85$ & $11 / 18 / 85$ & Braided channel area & Terrace & 29.0 & 27.1 & 5.9 & cll \\
\hline UE-25 UZN \#23 & Split Wash & 232859 & 172073 & 1232 & $11 / 19 / 85$ & $11 / 21 / 85$ & Canyon wall & Sideslope & 10.7 & 10.7 & 0.0 & cll \\
\hline USW UZ-N24 & Wren Wash & 234088 & 171314 & 1288 & $02 / 04 / 86$ & $02 / 26 / 86$ & Channel bottom & Channel & 22.9 & 9.1 & 0.2 & $\mathrm{cc}$ \\
\hline USW UZ-N25 & Wren Wash & 234217 & 171060 & 1321 & $02 / 11 / 86$ & $02 / 12 / 86$ & Channel bottom & Channel & 18.0 & 18.0 & 0.0 & ch \\
\hline USW UZ-N26 & Wren Wash & 234317 & 171000 & 1336 & $02 / 10 / 86$ & $02 / 11 / 86$ & Channel bottom & Channel & 10.7 & 10.7 & 0.0 & cll \\
\hline USW UZ-N27 & Yucca Crest & 235174 & 170344 & 1481 & $04 / 21 / 92$ & $04 / 30 / 92$ & Ridge & Ridgetop & 61.7 & 61.5 & 0.9 & cuc \\
\hline UE-25 UZN \#28 & Split Wash & 232590 & 172310 & 1206 & $11 / 21 / 85$ & $11 / 25 / 85$ & Braided channel area & Terrace & 8.1 & 7.6 & $8.1+$ & Qal \\
\hline UE-25 UZN \#29 & Split Wash & 232444 & 172265 & 1211 & $11 / 26 / 85$ & $11 / 27 / 85$ & Canyon wall dip slope & Terrace & 10.7 & 10.7 & 0.3 & cks \\
\hline UE-25 UZN \#30 & Split Wash & 232272 & 172283 & 1207 & $11 / 27 / 85$ & $12 / 02 / 85$ & Canyon wall dip slope & Terrace & 10.7 & 10.7 & 0.4 & cll \\
\hline USW UZ-N31 & Split Wash & 232942 & 171527 & 1266 & $09 / 03 / 92$ & $09 / 22 / 92$ & Channel bottom & Channel & 58.7 & 58.5 & 4.9 & ch \\
\hline USW UZ-N32 & Split Wash & 232959 & 171541 & 1267 & $09 / 23 / 92$ & $10 / 09 / 92$ & Sideslope & Sideslope & 63.2 & 62.8 & 0.7 & ch \\
\hline USW UZ-N33 & Drill Hole Wash & 234717 & 171051 & 1320 & $08 / 13 / 92$ & $08 / 18 / 92$ & Channel bottom & Channel & 22.9 & 22.5 & 4.0 & cc \\
\hline
\end{tabular}


Table 2. List of boreholes, location and altitude, drilling dates, description, depths, and lithology at Yucca Mountain--Continued

\begin{tabular}{|c|c|c|c|c|c|c|c|c|c|c|c|c|}
\hline $\begin{array}{c}\text { Borehole } \\
\text { designation }\end{array}$ & Location & $\begin{array}{l}\text { Northing } \\
\text { (meters) }\end{array}$ & $\begin{array}{l}\text { Easting } \\
\text { (meters) }\end{array}$ & $\begin{array}{l}\text { Altitude } \\
\text { (meters) }\end{array}$ & $\begin{array}{c}\text { Date } \\
\text { drilling } \\
\text { begun }\end{array}$ & $\begin{array}{c}\text { Date } \\
\text { drilling } \\
\text { com- } \\
\text { pleted }\end{array}$ & Topographic position & $\begin{array}{l}\text { Infiltra- } \\
\text { tion zono }\end{array}$ & $\begin{array}{c}\text { Total } \\
\text { depth } \\
\text { (meters) }\end{array}$ & $\begin{array}{c}\text { Depth } \\
\text { of } \\
\text { casing } \\
\text { (meters) }\end{array}$ & $\begin{array}{l}\text { Depth } \\
\text { to } \\
\text { bedrock } \\
\text { (meters) }\end{array}$ & $\begin{array}{l}\text { Lithol- } \\
\text { ogy } \\
\text { of } \\
\text { upper- } \\
\text { most } \\
\text { bed- } \\
\text { rock }\end{array}$ \\
\hline USW UZ-N34 & Drill Hole Wash & 234744 & 171069 & 1318 & $08 / 18 / 92$ & $08 / 24 / 92$ & Terrace & Terrace & 25.6 & 25.3 & 3.9 & $\mathrm{ym}$ \\
\hline USW UZ-N35 & HA Wash & 232338 & 171392 & 1295 & $10 / 13 / 92$ & $10 / 26 / 92$ & Braided channel area & Channel & 52.0 & 53.3 & 3.9 & cc \\
\hline USW UZ-N36 & Bleach Bone Ridge & 235885 & 171780 & 1415 & $02 / 28 / 92$ & $03 / 02 / 92$ & Ridge & Ridgetop & 18.2 & 18.1 & 0.8 & ccr \\
\hline USW UZ-N37 & Wren Wash & 233934 & 171820 & 1257 & $01 / 06 / 92$ & $01 / 30 / 92$ & Large channel bottom & Channel & 82.7 & 82.5 & 11.1 & ch \\
\hline USW UZ-N38 & Wren Wash & 233924 & 171707 & 1265 & 04/08/92 & 04/13/92 & Terrace & Terrace & 27.2 & 28.5 & 5.5 & $\operatorname{ch}$ \\
\hline USW UZ-N39 & Jackass Flats & 230165 & 188146 & 1149 & $08 / 18 / 93$ & $08 / 25 / 93$ & Terrace & Tẹrrace & 18.1 & 18.3 & $18.1+$ & Qal \\
\hline USW UZ-N40 & Coyote Wash & 233530 & 171975 & 1243 & $12 / 19 / 85$ & $01 / 07 / 86$ & Lower dip slope & Sideslope & 10.7 & 10.7 & 0.9 & cll \\
\hline USW UZ-N41 & Coyote Wash & 233436 & 171761 & 1255 & $12 / 12 / 85$ & $12 / 16 / 85$ & Channel bottom & Channel & 11.3 & 10.7 & 4.9 & cll \\
\hline USW UZ-N42 & Coyote Wash & 233394 & 171559 & 1274 & $12 / 16 / 85$ & $12 / 17 / 85$ & Channel bottom & C̣hannel & 12.2 & 10.7 & 0.0 & cll \\
\hline USW UZ-N43 & Coyote Wash & 233476 & 171683 & 1265 & $12 / 05 / 85$ & $12 / 09 / 85$ & Terrace & Terrace & 13.7 & 13.7 & 8.2 & ch \\
\hline USW UZ-N44 & Coyote Wash & 233536 & 171645 & 1269 & $12 / 18 / 85$ & $12 / 19 / 85$ & Channel bottom & Channel & 11.0 & 10.7 & 0.0 & cll \\
\hline USW UZ-N45 & Coyote Wash & 233470 & 171733 & 1259 & $12 / 09 / 85$ & $12 / 12 / 85$ & Channel bottom & Channel & 13.7 & 13.7 & 10.8 & ch \\
\hline USW UZ-N46 & Drill Hole Wash & 235385 & 170611 & 1372 & $01 / 21 / 86$ & $01 / 31 / 86$ & Large channel bottom & Channel & 30.2 & 30.2 & 0.0 & $\mathrm{ym}$ \\
\hline USW UZ-N47 & Drill Hole Wash & 235296 & 170622 & 1366 & $01 / 24 / 86$ & $01 / 29 / 86$ & Large channel bottom & Channel & 26.2 & 25.9 & 10.1 & ym \\
\hline USW UZ-N48, & WT-2 Wash & 231903 & 171424 & 1284 & $01 / 07 / 86$ & $01 / 08 / 86$ & Channel bottom & Channel & 10.7 & 10.7 & 0.0 & ch \\
\hline USW UZ-N49 & WT-2 Wash & 231910 & 171396 & 1289 & $01 / 09 / 86$ & $01 / 10 / 86$ & Canyon wall dip slope & Sideslope & 11.0 & 10.7 & 0.7 & cll \\
\hline USW UZ-N50 & WT-2 Wash & 231885 & 171576 & 1272 & $08 / 24 / 84$ & $08 / 24 / 84$ & Terrace & Terrace & 6.1 & 6.1 & 2.7 & ch \\
\hline USW UZ-N51 & WT-2 Wash & 231910 & 171575 & 1271 & $08 / 24 / 84$ & $08 / 24 / 84$ & Channel bottom & Channel & 6.1 & 6.1 & 4.3 & ch \\
\hline USW UZ-N52 & WT-2 Wash & 231920 & 171575 & 1272 & $08 / 24 / 84$ & $08 / 24 / 84$ & Terrace & Terrace & 7.6 & 7.6 & 2.1 & ch \\
\hline USW UZ-N53 & WT-2 Wash & 231677 & 171979 & 1236 & 05/19/92 & $06 / 12 / 92$ & Sideslope & Sideslope & 71.5 & 71.3 & 0.8 & cll \\
\hline USW UZ-N54 & WT-2 Wash & 231731 & 171987 & 1233 & $11 / 12 / 92$ & $12 / 10 / 92$ & Large channel bottom & Channel & 74.6 & $7 \dot{4} .4$ & 5.8 & cll \\
\hline USW UZ-N55 & WT-2 Wash & 231801 & 171983 & 1241 & 09/23/91 & $11 / 08 / 91$ & Sideslope & Sideslope & 77.8 & 78.0 & 0.7 & ch \\
\hline UE-25 UZN \#56 & WT-2 Wash & 231768 & 172358 & 1207 & $08 / 23 / 84$ & $08 / 23 / 84$ & Channel bottom & Channel & 18.3 & 18.3 & 17.1 & ch \\
\hline USW UZ-N57 & Abandoned Wash & 230174 & 170941 & 1276 & $10 / 28 / 92$ & $11 / 04 / 92$ & Sideslope & Sideslope & 36.2 & 36.0 & 0.7 & tc \\
\hline USW UZ-N58 & Abandoned Wash & 230197 & 170951 & 1274 & $11 / 05 / 92$ & $11 / 18 / 92$ & Channel bottom & Channel & 36.2 & 36.0 & 2.8 & tc \\
\hline USW UZ-N59 & Abandoned Wash & 230222 & 170959 & 1274 & $11 / 10 / 92$ & $12 / 08 / 92$ & Braided channel area & Channel & 36.2 & 36.0 & 4.6 & tc \\
\hline UE-25 UZN \#60 & WT-2 Wash & 231574 & 172690 & 1186 & $08 / 21 / 84$ & $08 / 23 / 84$ & Channel bottom & Channel & 10.7 & 10.7 & 8.1 & cks \\
\hline USW UZ-N61 & Abandoned Wash & 230239 & 170960 & 1275 & $12 / 09 / 92$ & $12 / 17 / 92$ & Sideslope & Sideslope & 36.2 & 36.0 & 3.1 & tc \\
\hline USW UZ-N62 & Yucca Crest & 230772 & 170171 & 1489 & 03/05/93 & 03/10/93 & Ridge & Ridgetop & 18.3 & 18.3 & 0.7 & cuc \\
\hline USW UZ-N63 & Pagany Wash & 234341 & 172568 & 1202 & 08/03/92 & $08 / 10 / 92$ & Sideslope & Terrace & 18.3 & 18.0 & 1.7 & $\mathrm{ch}$ \\
\hline USW UZ-N64 & Yucca Crest & 233394 & 170516 & 1460 & $04 / 16 / 92$ & 04/17/92 & Ridge & Ridgetop & 18.3 & 18.3 & 0.8 & cuc \\
\hline USW UZ-N65 & Highway Ridge & 231230 & 171461 & 1333 & $11 / 27 / 84$ & $11 / 27 / 84$ & Mid-ridge dip slope & Sideslope & 15.2 & 15.2 & 0.0 & cuc \\
\hline
\end{tabular}


$\overrightarrow{0}$ Table 2. List of boreholes, location and altitude, drilling dates, description, depths, and lithology at Yucca Mountain--Continued

\begin{tabular}{|c|c|c|c|c|c|c|c|c|c|c|c|c|}
\hline $\begin{array}{c}\text { Borehole } \\
\text { designation }\end{array}$ & Location & $\begin{array}{l}\text { Northing } \\
\text { (meters) }\end{array}$ & $\begin{array}{l}\text { Easting } \\
\text { (meters) }\end{array}$ & $\begin{array}{l}\text { Altitude } \\
\text { (meters) }\end{array}$ & $\begin{array}{l}\text { Date } \\
\text { drilling } \\
\text { begun }\end{array}$ & $\begin{array}{c}\text { Date } \\
\text { drilling } \\
\text { com- } \\
\text { pleted }\end{array}$ & Topographic position & $\begin{array}{l}\text { Infiltra- } \\
\text { tlon zone }\end{array}$ & $\begin{array}{c}\text { Total } \\
\text { depth } \\
\text { (meters) }\end{array}$ & $\begin{array}{l}\text { Depth } \\
\text { of } \\
\text { casing } \\
\text { (meters) }\end{array}$ & $\begin{array}{l}\text { Depth } \\
\text { to } \\
\text { bedrock } \\
\text { (meters) }\end{array}$ & $\begin{array}{l}\text { Lithol- } \\
\text { ogy } \\
\text { of } \\
\text { upper- } \\
\text { most } \\
\text { bed } \\
\text { rock }\end{array}$ \\
\hline USW UZ-N66 & Highway Ridge & 231171 & 171261 & 1328 & $11 / 27 / 84$ & $11 / 28 / 84$ & Mid-ridge dip slope & Sideslope & 15.2 & 15.2 & 0.0 & cks \\
\hline USW UZ-N67 & Dune Wash & 229708 & 171846 & 1195 & $07 / 25 / 84$ & $07 / 25 / 84$ & Channel bottom & Channel & 7.6 & 7.6 & 5.8 & ccr \\
\hline USW UZ-N68 & Dune Wash & 229808 & 171909 & 1196 & $07 / 25 / 84$ & $07 / 25 / 84$ & Braided channel area & Channel & 16.8 & 16.8 & 15.2 & $\operatorname{Tmr}$ \\
\hline USW UZ-N69 & Dune Wash & 229960 & 172030 & 1194 & $07 / 26 / 84$ & $07 / 26 / 84$ & Channel bottom & Channel & 10.7 & 10.7 & 8.2 & Tmr \\
\hline USW UZ-N70 & Wren Wash & 234468 & 170738 & 1384 & $02 / 06 / 86$ & $02 / 10 / 86$ & Channel bottom & Channel & 10.7 & 10.7 & 0.0 & cll \\
\hline USW UZ-N71 & Yucca Crest & 231961 & 170202 & 1501 & $05 / 18 / 84$ & $05 / 18 / 84$ & Upper ridge dip slope & Ridgetop & 15.9 & 15.8 & 0.0 & ccr \\
\hline USW UZ-1472 & Yucca Crest & 231974 & 170269 & 1490 & $11 / 20 / 84$ & $11 / 20 / 84$ & Upland channel bottom & Ridgetop & 9.1 & 9.1 & 0.0 & cuc \\
\hline USW UZ-N73 & Yucca Crest & 231968 & 170361 & 1483 & $11 / 20 / 84$ & $11 / 21 / 84$ & Upland channel bottom & Ridgetop & 9.1 & 9.1 & 0.0 & cul \\
\hline USW UZ-N74 & Yucca Crest & 232063 & 170249 & 1495 & $02 / 18 / 86$ & $02 / 18 / 86$ & Upper ridge dip slope & Ridgetop & 11.3 & 10.7 & 0.0 & ccr \\
\hline USW UZ-N75 & Yucca Crest & 232094 & 170406 & 1463 & $02 / 19 / 86$ & $02 / 20 / 86$ & Upper ridge dip slope & Ridgetop & 11.3 & 10.7 & 0.7 & cuc \\
\hline USW UZ-N76 & Yucca Crest & 232060 & 170398 & 1511 & $11 / 21 / 86$ & $11 / 26 / 86$ & Upper ridge dip slope & Ridgetop & 12.2 & 10.7 & 0.2 & cuc \\
\hline USW UZ-N77 & Solitario Canyon & 230284 & 168980 & 1189 & $11 / 30 / 84$ & $11 / 30 / 84$ & Large channel bottom & Channel & 15.2 & 15.2 & 11.6 & cks \\
\hline USW UZ-N78 & Solitario Canyon & 230904 & 169549 & 1275 & $12 / 10 / 84$ & $12 / 11 / 84$ & Canyon wall & Sideslope & 9.1 & 9.1 & 0.0 & ccr \\
\hline USW UZ-N79 & Solitario Canyon & 230957 & 169571 & 1266 & $12 / 07 / 84$ & $12 / 10 / 84$ & Channel bottom & Channel & 9.8 & 9.8 & 0.0 & cul \\
\hline USW UZ-N80 & Solitario Canyon & 230927 & 169835 & 1320 & $12 / 06 / 84$ & $12 / 07 / 84$ & Upland channel bottom & Sideslope & 15.9 & 15.8 & 0.0 & tnl \\
\hline USW UZ-N81 & Solitario Canyoń & 230980 & 169345 & 1239 & $12 / 03 / 84$ & $12 / 06 / 84$ & Channel bottom & Channel & 21.3 & 21.3 & 1.8 & cks \\
\hline USW UZ-N82 & Solitario Canyon & 230885 & 169070 & 1212 & $11 / 30 / 84$ & $12 / 03 / 84$ & Large channel bottom & Channel & 12.2 & 12.2 & 6.7 & cul \\
\hline USW UZ-N83 & Solitario Canyon & 231838 & 169575 & 1267 & $12 / 12 / 84$ & $12 / 13 / 84$ & Small channel bottom & Sideslope & 21.3 & 21.3 & 0.0 & cks \\
\hline USW UZ-N84 & Solitario Canyon & 231867 & 169435 & 1253 & $12 / 12 / 84$ & $12 / 19 / 84$ & Terrace & Terrace & 13.7 & 13.7 & 6.1 & ccr \\
\hline UE-25 UZN \#85 & 40-Mile Wash & 228818 & 176043 & 1017 & $05 / 06 / 85$ & $05 / 08 / 85$ & Terrace & Terrace & 24.4 & 24.4 & $24.4+$ & Qal \\
\hline USW UZ-N86 & Solitario Canyon & 231835 & 169609 & 1272 & $12 / 18 / 84$ & $12 / 18 / 84$ & Small channel bottom & Sideslope & 9.1 & 9.1 & 0.0 & cks \\
\hline USW UZ-N87 & Solitario Canyon & 231866 & 169434 & $1253^{\prime}$ & $12 / 20 / 84$ & $12 / 20 / 84$ & Terrace & Terrace & 13.7 & 13.7 & 5.8 & ccr \\
\hline USW UZ-N88 & Solitario Canyon & 231891 & 169637 & 1281 & $12 / 17 / 84$ & $12 / 17 / 84$ & Canyon wall & Sideslope & 9.1 & 9.1 & 0.2 & cul \\
\hline USW UZ-N89 & Solitario Canyon & 231834 & 169344 & 1247 & $12 / 19 / 84$ & $12 / 19 / 84$ & Large channel bottom & Channel & 13.7 & 13.7 & 10.1 & cks \\
\hline USW UZ-N90 & Solitario Canyon & 231833 & 169343 & 1247 & $12 / 14 / 84$ & $12 / 17 / 84$ & Large channel bottom & Channel & 13.7 & 13.7 & 9.9 & cul \\
\hline UE-29 UZN \#91 & 40-Mile Wash & 243009 & 178412 & 1112 & $01 / 16 / 86$ & $01 / 21 / 86$ & Large channel bottom & Channel & 28.7 & 27.1 & 19.5 & tu \\
\hline UE-29 UZN \#92 & 40-Mile Wash & 237137 & 177869 & 1118 & $01 / 13 / 86$ & $01 / 15 / 86$ & Large channel bottom & Channel & 36.6 & 32.0 & 17.7 & $\mathfrak{t u}$ \\
\hline USW UZ-N93 & Yucca Crest & 231521 & 170176 & 1501 & $07 / 27 / 84$ & $07 / 28 / 84$ & Disturbed area-drill pad & & 12.2 & 12.2 & 0.0 & ccr \\
\hline USW UZ-N94 & Yucca Crest & 231564 & 170150 & 1501 & $08 / 15 / 84$ & $08 / 15 / 84$ & Disturbed area-drill pad & & 9.1 & 9.1 & 0.0 & ccr \\
\hline USW UZ-N95 & Yucca Crest & 231617 & 170131 & 1502 & $08 / 15 / 84$ & $08 / 16 / 84$ & Disturbed area-drill pad & & 6.1 & 6.1 & 0.0 & $\mathrm{ccr}$ \\
\hline USW UZ-N96 & Yucca Crest & 231479 & 170201 & 1491 & $08 / 16 / 84$ & $08 / 16 / 84$ & Upper ridge dip slope & Sideslope & 10.7 & 10.7 & 0.6 & ccr \\
\hline UE-25 UZN \#97 & Split Wash & 232591 & 172310 & 1206 & $11 / 25 / 85$ & $11 / 26 / 85$ & Braided channel area & Terrace & 18.3 & 18.3 & 17.7 & cll \\
\hline USW UZ-N98 & Wren Wash & 234085 & 171323 & 1287 & $02 / 20 / 86$ & $02 / 25 / 86$ & Channel bottom & Channel & 22.9 & 9.4 & 0.3 & cc \\
\hline USW UZ-7 & WT-2 Wash & 231903 & 171575 & 1279 & $01 / 04 / 85$ & $01 / 22 / 85$ & Channel & Channel & 62.9 & 6.1 & 6.7 & cc \\
\hline
\end{tabular}




\section{EVALUATION OF INFILTRATION PROCESSES}

\section{Moisture Profiles}

The winter of 1991 produced enough precipitation to end the drought of the previous 6 years. Volumetric water content before this time was low throughout the borehole profiles, as low as they ever were during the study period, and are shown as examples in boreholes N7, N14, and N71 (fig. 4). By October 1992, an increase in soil or bedrock volumetric water content was apparent. The water content continued to generally increase in all boreholes over the next 18 months. The extent of the increase in water content varied among boreholes in different topographic positions, as measured by the volume of water and by the depth of the infiltrating pulses. The moisture profiles in the channel and terrace boreholes (figs. $4 a$ and $4 b$ ) are similar. The water did not penetrate very deeply (about 2-3 m) over this time period, and most of the water was held close to the surface in the soils that have large storage capacities. These topographic positions are similar during this period, because borehole N7, in the channel, was not exposed to any runoff events. The boreholes in sideslope positions that have shallow soils (figs. 4c and 4d) exhibit deeper penetration of the water. Smaller volumes of water are held in the upper portions of these profiles because of the lower bedrock porosity, and the penetration of water is especially deep (about $13 \mathrm{~m}$ ) in the north-facing slope at N53, possibly due to lower ET, which is a function of the low available solar radiation load for much of the winter. Infiltration of water in the ridgetop boreholes (figs. $4 \mathrm{e}$ and $4 \mathrm{f}$ ), regardless of whether or not the boreholes have soil cover, is greater in volume than for all the other locations, and especially in N71 at the surface and at depth in N 15, a borehole located in a small ridgetop channel. In the boreholes that have thick soils and large storage capacity, the volume of water may be the same as for boreholes located along the ridgetops, but it is stored higher in the profile in the former. Where there is little storage capacity near the surface, water is generally observed to infiltrate deeper. In addition, the shallower infiltration in the washes may be due, in large part, to the presence of low-porosity restricting layers. For example, boreholes N7 and N15 (figs. 4a and 4f) are both in channels, but the much deeper penetration of water in N15 can be attributed to its thinner soil cover, relatively high-porosity bedrock, and highconductivity fractures, as well as having greater runoff from winter snowmelt. In contrast, N7 generally receives less snow than does the ridgetop, and the infil- tration in N7 is stored at shallower depths because of subsurface- restricting layers that have porosities of less than 15 percent.

The difference between channel and terrace boreholes can be seen following a runoff event in August 1984, in the channel at N13 adjacent to terrace borehole N14 (figs. Sa and b). The boreholes were initially logged August 15 and 16, 1984. A rainfall event occurred August 20 and the boreholes were logged again August 20 and 21 and several times over the next few months. N14 shows typical terrace behavior with the surface wetting up to, but not penetrating below about $2 \mathrm{~m}$, due to ET processes and possibly some lateral diversion due to restrictive caliche layers. N13, on the other hand, shows evidence of a pulse of water penetrating throughout the depth of the borehole from between August and the following May.

\section{Change in Volumetric Water Content}

A time series of water-content changes in boreholes in different positions provides information regarding rate and timing of infiltration for a 3.3-year period (fig. 6). Changes in volumetric water content in the uppermost $1 \mathrm{~m}$ occur with precipitation cycles, wetting in the winter and drying out in the summer. The second-meter depth lags behind the top meter in the channel borehole by a few months, whereas there is no increase in volumetric water content deeper than $2 \mathrm{~m}$. In the sideslope borehole, the same result is noted in the upper 1-m depth interval and in the second-meterdepth interval and, after 3.3 years, is beginning to be recorded in the lower-depth intervals. The ridgetop borehole shows no increase in moisture until 1992, when the entire profile responds to the annual precipitation and indicates relatively deep and fast infiltration. These changes with time and depth indicate different rates of infiltration for these three boreholes: water in the channel borehole penetrates more slowly than in the other two, and the ridgetop borehole increases in volumetric water content throughout its whole profile with no time lag.

\section{Depth of Moisture Penetration}

Depth of penetration of water can be estimated from long-term records of volumetric water content and can be used to suggest a depth of infiltration. If an estimate can be made of a depth below which infiltration becomes net infiltration, then this depth of penetration is a useful characteristic. This depth is generally assumed to be the depth below that in which ET pro- 

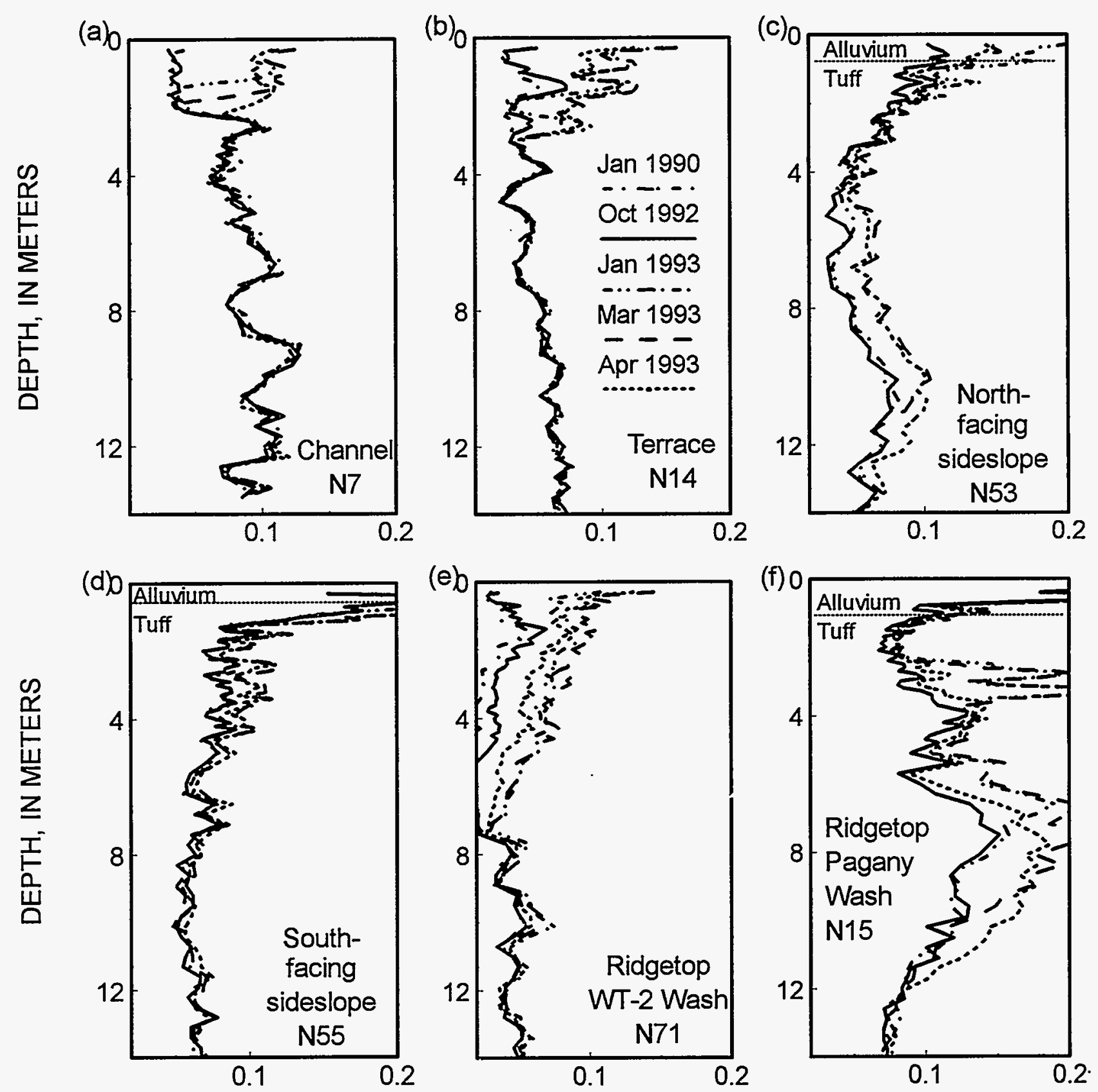

VOLUMETRIC WATER CONTENT

Figure 4. Moisture profiles from boreholes at Yucca Mountain in each of the topographic positions from January 1990 through April 1993. 
(a)

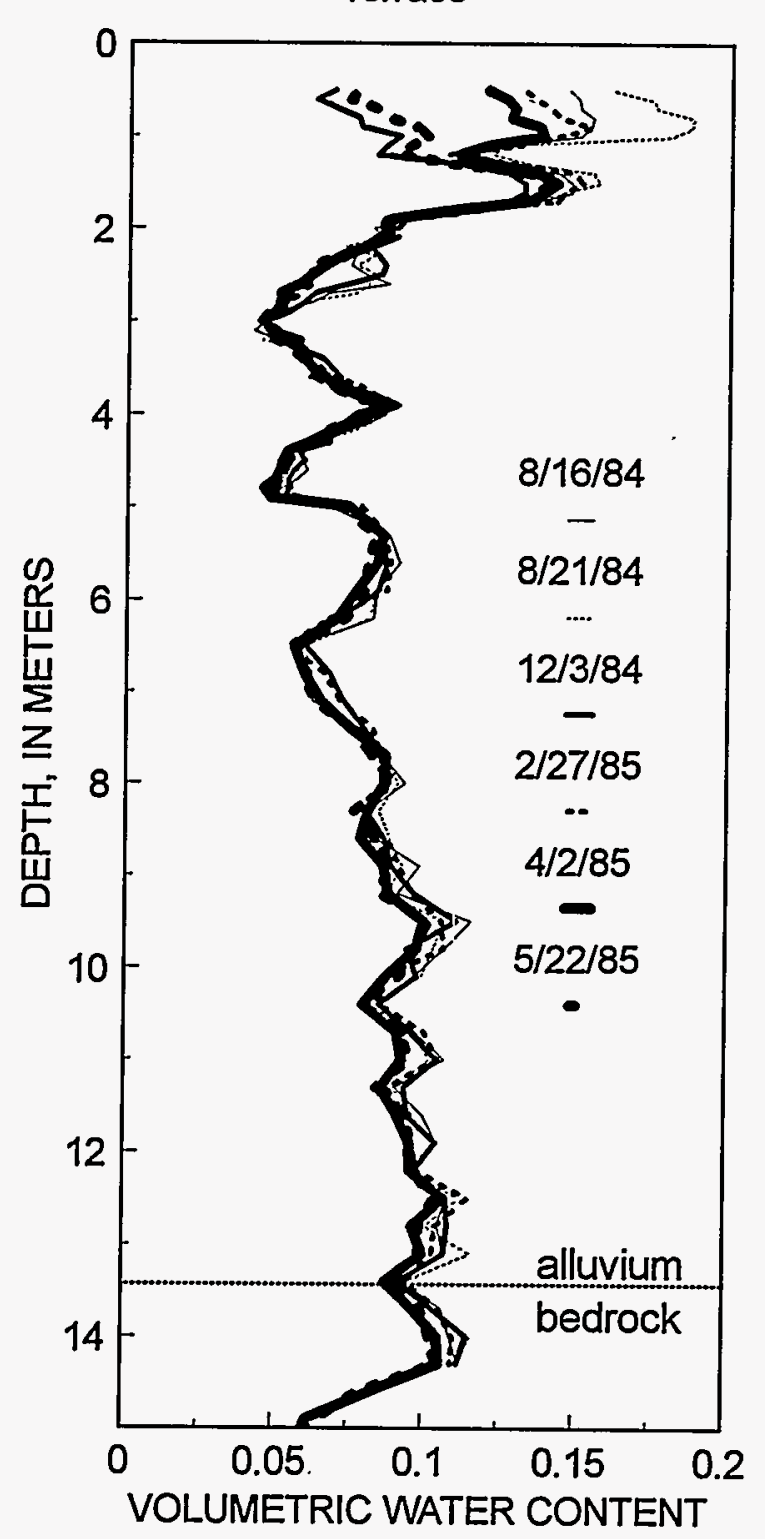

(b)

\section{UE-25 UZN \#13}

Channel

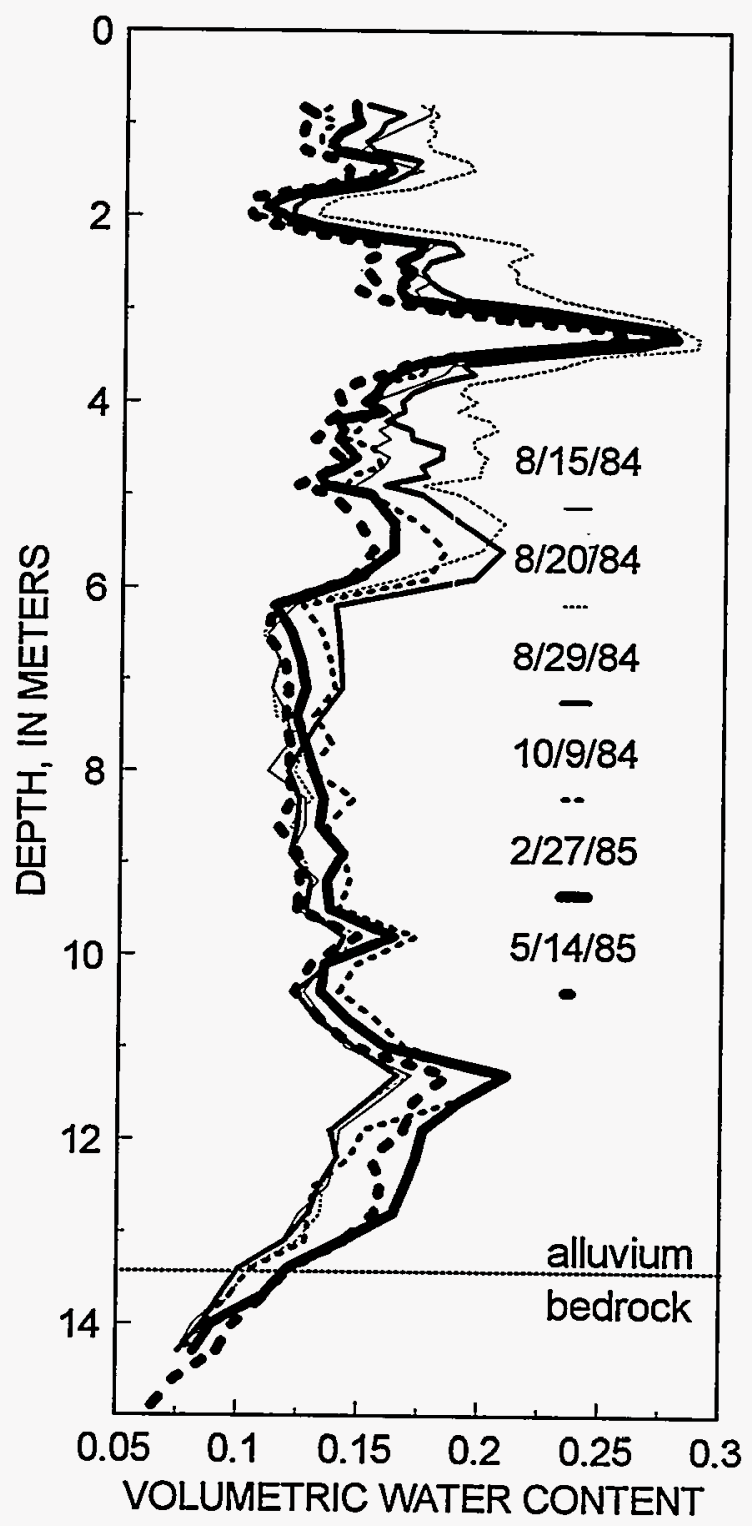

Figure 5. Volumetric water content with depth for (a) terrace and (b) channel neutron holes at Yucca Mountain before and after runoff event, August 20, 1984. 


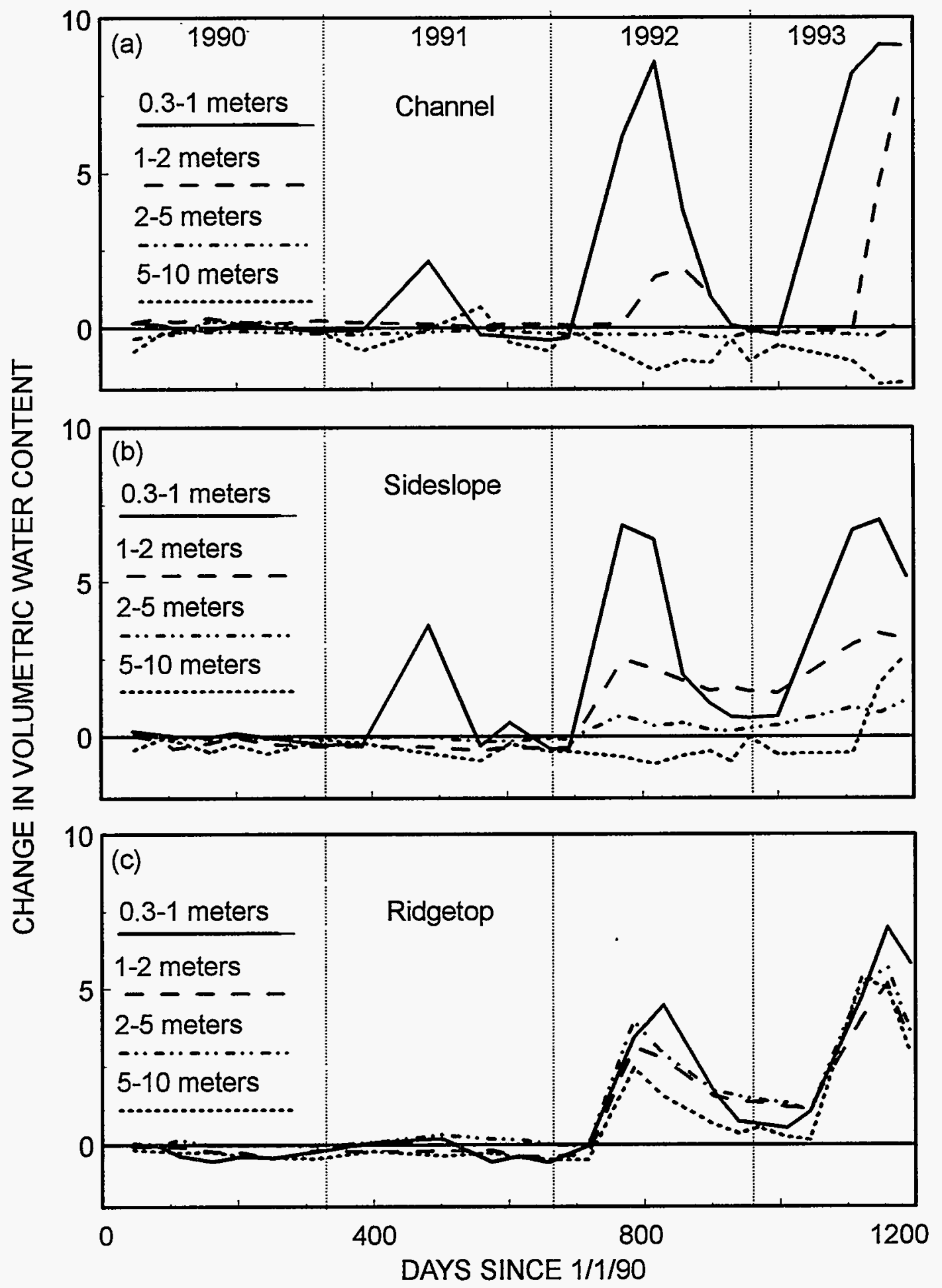

Flgure 6. Change in volumetric water content, in millimeters, for four depth intervals over a 3.3-year period at Yucca Mountain for boreholes from channel, sideslope, and ridgetop positions. 
cesses occur and will, therefore, vary with plant species of different rooting depth, as well as with radiation load. If, however, the pulses of water penetrate below the alluvium and into the bedrock where few or no plant roots occur, then the likelihood for infiltration to become net infiltration increases.

The depth of infiltration was estimated for logs from 34 borcholes located in two washes, Pagany Wash to the north of the potential repository location, and WT-2 Wash to the south. Both washes include ridgetop, sideslope, terrace, and channel topographic positions. Estimates of infiltration depth are shown for data collected in boreholes from January 1990 though December, with the corresponding thickness of alluvium for each borehole (fig. 7). In general, the depth of infiltration in the channels does not exceed the depth of alluvium. In several boreholes, the downward component of infiltration halts at the tuff/alluvium interface (for example, channel boreholes N31 and N33), indicating a barrier due to the lower conductivity and lower storage capacity in the lower porosity bedrock. Channel boreholes $N 91$ and $N 92$ are located about $20 \mathrm{~km}$ to the north in Fortymile Canyon, which has a different climatic regime with a shallow water table and much higher recharge rate. These boreholes are not included in any analysis that follows but are shown only for reference.

Means and standard deviations were calculated for the depth of infiltration and the depth of alluvium for the boreholes in the four topographic positions and are shown in table 3. In the table, the depth of infiltration in the terrace boreholes is only slightly less at $2.8 \mathrm{~m}$ than in the channel boreholes at $3.4 \mathrm{~m}$. The sideslope and ridgetop boreholes have much shallower alluvial cover, both with a mean of $0.5 \mathrm{~m}$, yet have depths of infiltration to about 5.5 and $5.4 \mathrm{~m}$, respectively, probably deeper than the zone in which ET processes occur. The volumes of water at this depth are probably small, however, as suggested by most of the sideslope and ridgetop holes in the Supplemental Data section. For example, N2 (2.5 m), N17 (7 m), and N23 $(4.8 \mathrm{~m})$, all have changes in volumetric water content at depth of no more than $0.05 \mathrm{~cm}^{3} / \mathrm{cm}^{3}$.

\section{SUMMARY AND CONCLUSIONS}

The analysis of moisture profiles in 99 boreholes from four topographic positions at Yucca Mountain included both quantitative and subjective methods and represented a large areal coverage over a 9-year period of time. Analyses of the measured profiles indicated that the thinner the soil cover, that is, storage capacity, the deeper the measured increase in volumetric water content, indicating greater net infiltration, which is especially evident when surface flow concentrates runoff at locations underlain by fractured bedrock. The more deeply the water penetrates, the less likely that it will be lost to evapotranspiration. When surface flow is negligible, the deepest infiltration was on the ridgetops and the shallowest infiltration was in the washes, although there is little difference in infiltration characteristics between the terrace and channel boreholes. Exceptions were noted following appreciable runoff events. For these cases, large volumes of water often infiltrated more than $5 \mathrm{~m}$ into the soil in the washes, which is below the estimated root zone. At these sites, however, conditions causing significant channel runoff occurred episodically and only in a few washes during any single event. In addition, the active channels where runoff occurs comprise less than 2 percent of the surface area of the watersheds, and therefore, are not considered to contribute significantly to overall net infiltration in the watershed. More precipitation infiltrates during the winter when the evapotranspiration is low and runoff is rare, due to lower intensity storms and to slowly melting snow on the ridgetops for several weeks each winter. This slow rate of input over long periods allows for larger volumes of water to penetrate below the root zone and thereby escape the high evapotranspiration demands of the following summer.

A conceptual model of shallow infiltration processes at Yucca Mountain was developed to categorize the site into four zones that generally can be identified on the basis of the manner in which volumetric water contents change with depth and time. The zones are described as follows: (1) The ridgetop is flat to gently sloping, higher in elevation, exposed to climatic effects, and has thin soils mostly developed in place with clays and higher water-holding capacity that reduces rapid evaporation. The ridgetops generally are located where the bedrock is moderately to densely welded and fractured. These conditions lead to deeper penetration than in the other topographic positions, and to smaller volumes of water. In some locations, however, where runoff is channeled, large volumes of water can infiltrate; (2) sideslopes are steep and commonly have thin to no soil cover and usually developed in welded, fractured tuff, which creates conditions conducive to rapid runoff. The low storage capacity of the thin soil cover and the exposure of fractures at the surface may enable small volumes of water to infiltrate to greater depths, especially on slopes with north-facing exposures and, therefore, lower evapotranspiration demands. Shallow alluvium at the bases of the slopes can easily become saturated and initiate flow into the underlying fractures; (3) alluvial terraces are flat, broad deposits of layered rock fragments and fine soil with a large storage capacity. There is, therefore, little runoff 


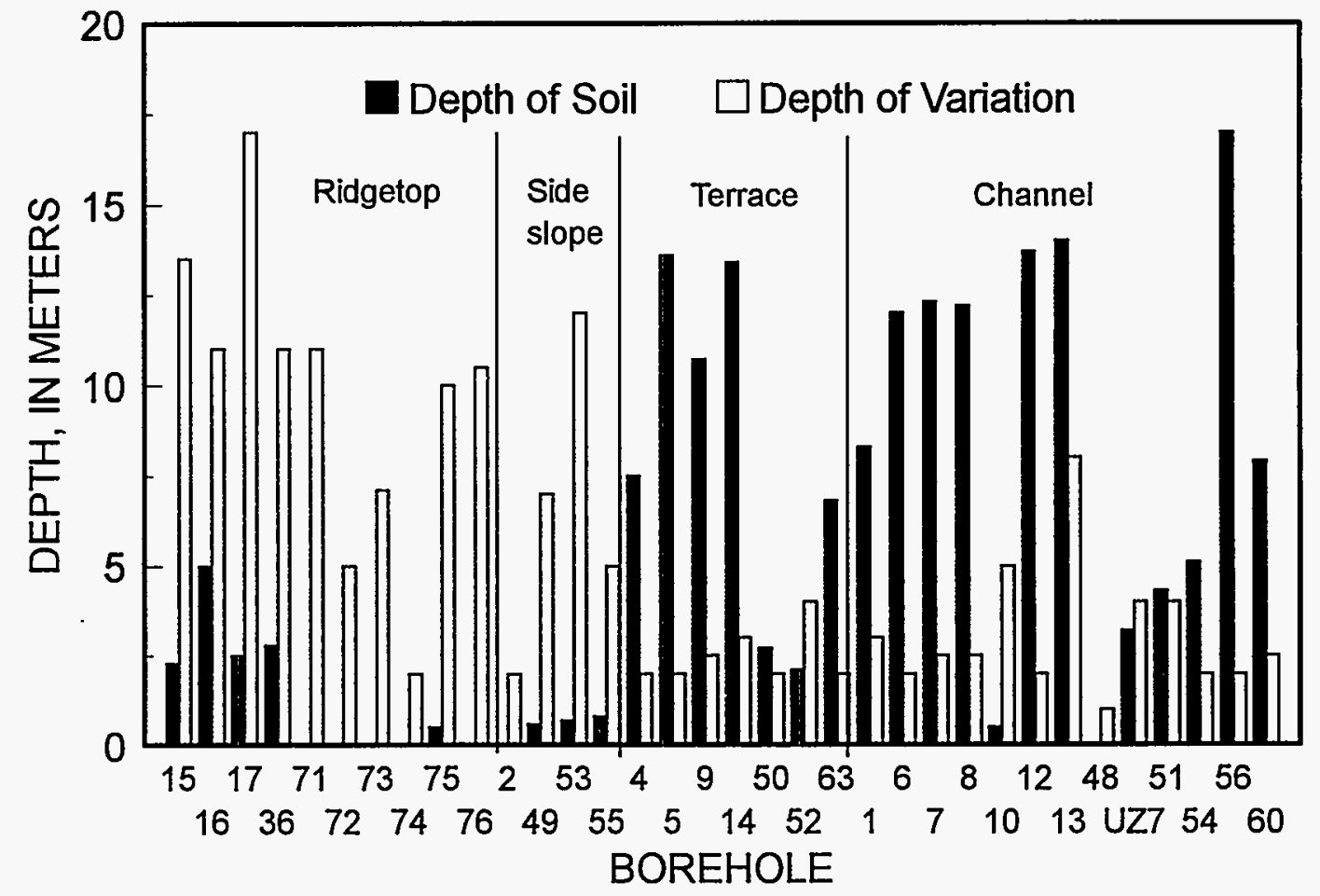

Figure 7. Depth of water-content variation and depth of soil cover at Yucca Mountain for 34 boreholes.

Table 3. Mean and standard deviation for the depth of alluvium and estimated depth of penetration of seasonal infiltrating water in all boreholes, except in N91 and N92, in channels, terraces, sideslopes, and ridgetops, at Yucca Mountain, Nevada

\begin{tabular}{lccccc}
\hline \multirow{2}{*}{$\begin{array}{c}\text { Topographic } \\
\text { position }\end{array}$} & \multicolumn{2}{c}{$\begin{array}{c}\text { Depth of alluvium, } \\
\text { in meters }\end{array}$} & $\begin{array}{c}\text { Depth of infiltration, } \\
\text { in meters }\end{array}$ & $\begin{array}{c}\text { Number of } \\
\text { boreholes }\end{array}$ \\
\cline { 2 - 5 } & Mean & $\begin{array}{c}\text { Standard } \\
\text { deviation }\end{array}$ & Mean & $\begin{array}{c}\text { Standard } \\
\text { deviation }\end{array}$ & \\
\hline Channel & 7.2 & 5.6 & 3.4 & 1.5 & 43 \\
Terrace & 7.9 & 6.4 & 2.8 & 1.2 & 20 \\
Sideslope & 0.5 & 0.7 & 5.5 & 4.7 & 17 \\
Ridgetop & 0.5 & 0.5 & 5.4 & 3.2 & 17 \\
\hline
\end{tabular}


and little movement of water to any depth in the profile before evapotranspiration removes it. Consequently, this zone contributes the least to net infiltration in the watershed; and (4) active channels differ little from the terraces but are located in a position to collect and concentrate runoff which, although it occurs infrequently, can then penetrate deeply. However, this mechanism is not considered to be a major contributor to net infiltration because of the infrequency of precipitation resulting in runoff and because the channels encompass a very small percentage of the watershed area.

There are numerous heterogeneities and exceptions to this categorization. In general, however, changes in moisture profiles over time measured at a borehole tend to be characterized by the conceptual model zone in which the site is located. These locations can be used to identify the infiltration mechanisms and to aid in the estimation of upper boundary conditions, necessary for the development of largescale watershed models. In an environment that has a high evaporative demand, it is more important to assess the depth-of-water penetration than the volume of water entering the profile in order to estimate net infiltration. This penetration is influenced by the potential for surface storage (depth of soils, layering and caliche, slope and aspect), the timing of the precipitation (winter or summer), the presence of fractures, and the relative saturation of the wetting front when it reaches fractured bedrock.

\section{REFERENCES CITED}

De Bruin, H.A.R., 1988, Evaporation in Arid and Semi-Arid Regions in Estimation of natural groundwater recharge, Simmers, I., ed., NATO ASII Series C: Mathematical and physical sciences, Dordrecht, Holland, D. Reidel Publishing Co., v. 222, p. 73-88.

Dreiss, S.J., and Anderson, L.D., 1985, Estimating vertical soil moisture flux at a land treatment site: Groundwater, v. 23 , no. 4, p. 503-511.

Flint, L.E., Flint, A.L., and Hevesi, J.A., 1994, Shallow infiltration processes in arid watersheds at Yucca Mountain, Nevada: Proceedings, International High Level Nuclear Waste Conference, Las Vegas, Nev., May 1994, v. 4, p. 2315-2322.

Hammermeister, D.P., Blout, D.O., and McDaniel, J.C., 1985 , Drilling and coring methods that minimize the disturbance of cuttings, core and rock formation in the unsaturated zone, Yucca Mountain, Nevada: Proceedings of the National Water Well Association Conference on Characterization and Monitoring of the Vadose (Unsaturated) Zone, National Water Well Association, p. 507-541.

Hevesi, J.A., Flint, A.L., and Istok, J.D., 1992, Precipitation estimation in mountainous terrain using multivariate geostatistics-Part II-Isohyetal maps: Journal of Applied Meteorology, v. 31, p. 677-688.

Klenke, J.M., and Flint, A.L., 1991, A collimated neutron tool for the measurement of soil-water content: Soil Science Society of America Journal, v. 55, no. 4, p. 916-922.

O'Farrell, T.P., and Collins, E., 1983, 1982 Biotic survey of Yucca Mountain, Nevada Test Site, Nye County, Nevada: EG\&G Energy Measurements Report EGG 10282-2004, S-753-R, $38 \mathrm{p}$.

Sawyer, D.A., Fleck, R.J., Lanphere, M.A., Warren, R.G., Broxton, D.E., and Hudson, M.R., 1994, Episodic caldera volcansim in the Miocene southwestern Nevada volcanic field-Revised stratigraphic framework, ${ }^{40} \mathrm{Ar} /{ }^{39} \mathrm{Ar}$ geochronology, and implications for magmatism and extension: Geological Society of America Bulletin, v. 106, p. 1304-1318.

Scott, R.B., and Bonk, J., 1984, Preliminary geologic map of Yucca Mountain, Nye County, Nevada, with geologic sections: U.S. Geological Survey Open-File Report 84-494.

Tyler, S.W., 1988, Neutron moisture meter calibration in large diameter boreholes: Soil Science Society of America Journal, v. 52, no. 3, p. 890-892.

Winograd, I.J., and Thordarson, W., 1975, Hydrogeologic and hydrochemical framework, south-central Great Basin, Nevada-California, with special reference to the Nevada Test Site: U.S. Geological Survey Professional Paper 712-C, $126 \mathrm{p}$.

Wittwer, C.S., Bodvarsson, G.S., Chornack, M.P., Flint, A.L., Flint, L.E., Lewis, B.D., Spengler, R.W., and Rautman, C.A., 1992, Development of a threedimensional site-scale model for the unsaturated zone at Yucca Mountain, Nevada: Proceedings, International High Level Nuclear Waste Conference, Las Vegas, Nev., April 1992, v. 1, p. 263-271. 


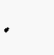


SUPPLEMENTAL DATA: WATER CONTENT WITH

DEPTH FOR 99 NEUTRON HOLES FROM JANUARY 1990 THROUGH DECEMBER 1993 


\section{Discussion and Use of Moisture Profiles}

The entire data set from May 1984 through December 1993, about 14 megabytes of disk space, can be obtained from the Department of Energy in ASCII format.

Figures 8-106 in this supplemental data section includes a graphical representation of all data collected from January 1990 through December 1993. Inclusion of the entire data set would have resulted in graphics that were difficult to visualize. January 1990 was chosen as a beginning date, because 1990 was near the end of the drought and that summer included the driest measurements ever collected for the boreholes. Above normal rainfall in 1991-92 included most of the wettest measurements ever collected. These graphs, therefore, represent the range of moisture conditions encountered in the boreholes. All data are represented as volumetric water content versus depth of borehole, and all graphs are scaled to $0.40 \mathrm{~cm}^{3} / \mathrm{cm}^{3}$ volumetric water content, although the depth scale differs for each hole. The depth of alluvium, or the alluvium/tuff contact, is noted by a dotted line on each graph; if no line is shown, then the borehole has no alluvial cover or is alluvium to total depth. The borehole designation, general site location, and topographic position (designated as infiltration zone in table 2) also are included on each graph. No topographic position is indicated for N93, N94, and N95, which are located on a drill pad on Yucca Crest. Graphs are generally organized by wash and proximity of boreholes to each other.

Data points include all individual measurements over the 3-yr. period (January 1990 through December 1993). This representation shows the range in volumetric water content, the depth where changes in water content were the greatest, and approximately how deep water penetrated. Points that are high outliers at the bottom of many of the holes are probably readings that were taken when the neutron probe was slightly below the bottom of the cased interval. This is not always the case, however; for example, water was observed in the bottom of N2 on several occasions and would account for the indicated high-water content. Even though the calibration equations were developed for calculating water content of the formation through a casing wall, there was no assurance that some of those points were not real increases in water content, so none of them were omitted. Several graphs indicate negative water content, probably because the linear calibration equations do not adequately represent conditions at very low-water content. Alternatively, washout zones behind the casing can show up as fewer counts and are interpreted as low, or occasionally negative, water content. These issues are currently being investigated more thoroughly by using other types of borehole geophysical measurements, developing regression equations for different lithologies, developing non-linear equations, and measuring capture cross sections for various lithologies. The calibration equations will be updated.

Several of the graphs are noteworthy and deserve comment. $\mathrm{N} 10$ (fig. 17) has several measurements below 19.4 meters that represent only a single set of measurements to the total depth of this borehole. N15 (fig. 22) shows considerable scatter to almost $10 \mathrm{~m}$. This borehole is in a small channel at the headwaters of Pagany Wash, where runoff from melting snow was observed for several weeks during the spring of 1992. N91 (fig. 98) is located in a channel and was drilled to the water table, which is at approximately $20 \mathrm{~m}$. This location in upper Fortymile Wash has regular runoff in the wash, with about twice the rainfall each year as Yucca Mountain receives. N92 (fig. 99) is not in the main channel and does not receive as much runoff as N91, which is in the main channel. N28 (fig. 35) and N97 (fig. 104) are located in Split Wash in a terrace location and are about $1.5 \mathrm{~m}$ apart. Even given their proximity, when scaled to the same depth, their profiles are a little different, especially at $2.5 \mathrm{~m}$. This may be due to a washout zone in N97, or the proximity of a large boulder in N28. N50 (fig. 57), UZ7 (fig. 107), N51 (fig. 58), and N52 (fig. 59) are located in WT-2 Wash, and all reflect relatively large changes in water content to about 3 or $4 \mathrm{~m}$ due to several runoff events in that wash. Two boreholes, N55 (fig. 62) and N73 (fig. 80), have points that stand out that can be explained by seasonal flow through fractures or faults that intersect these boreholes below the alluvium. These points occur repeatedly, usually during the winter high-rainfall months. Several boreholes, most noticeably N64 (fig. 71), show a large difference between water contents in the winter months and those in the drier months. This contrast is attributed to the highly-fractured, low-porosity bedrock. Water is retained in the matrix throughout the summer. The fractures hold larger volumes of water during the wet season but, due to their large apertures, drain rapidly rather than dry out slowly. Consequently, the moisture profiles do not show a continuum. This shows up in the graph as matrix water content (at $4 \mathrm{~m}$, about $0.04 \mathrm{~cm}^{3} / \mathrm{cm}^{3}$ ) in the summer and matrix plus fracture water content (at $4 \mathrm{~m}$, about $0.10 \mathrm{~cm}^{3} / \mathrm{cm}^{3}$ ) in the winter. 
SUPPLEMENTAL DATA: FIGURES 


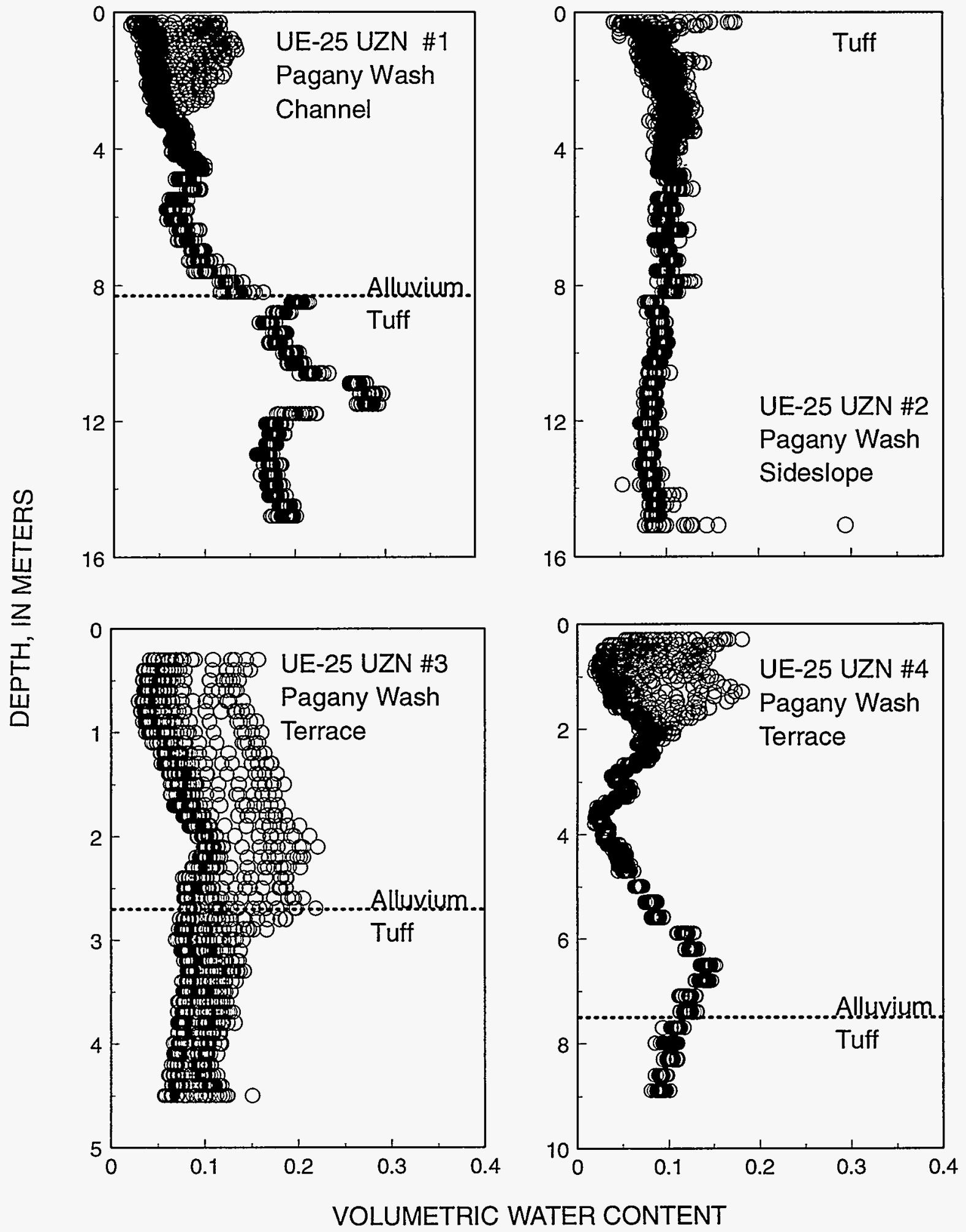

Figures 8-11. Volumetric water content with depth for boreholes UE-25 UZN \#1, UE-25 UZN \#2, UE-25 UZN \#3, and UE-25 UZN \#4. All points measured from 1/1/90 through 12/31/93 are shown. 


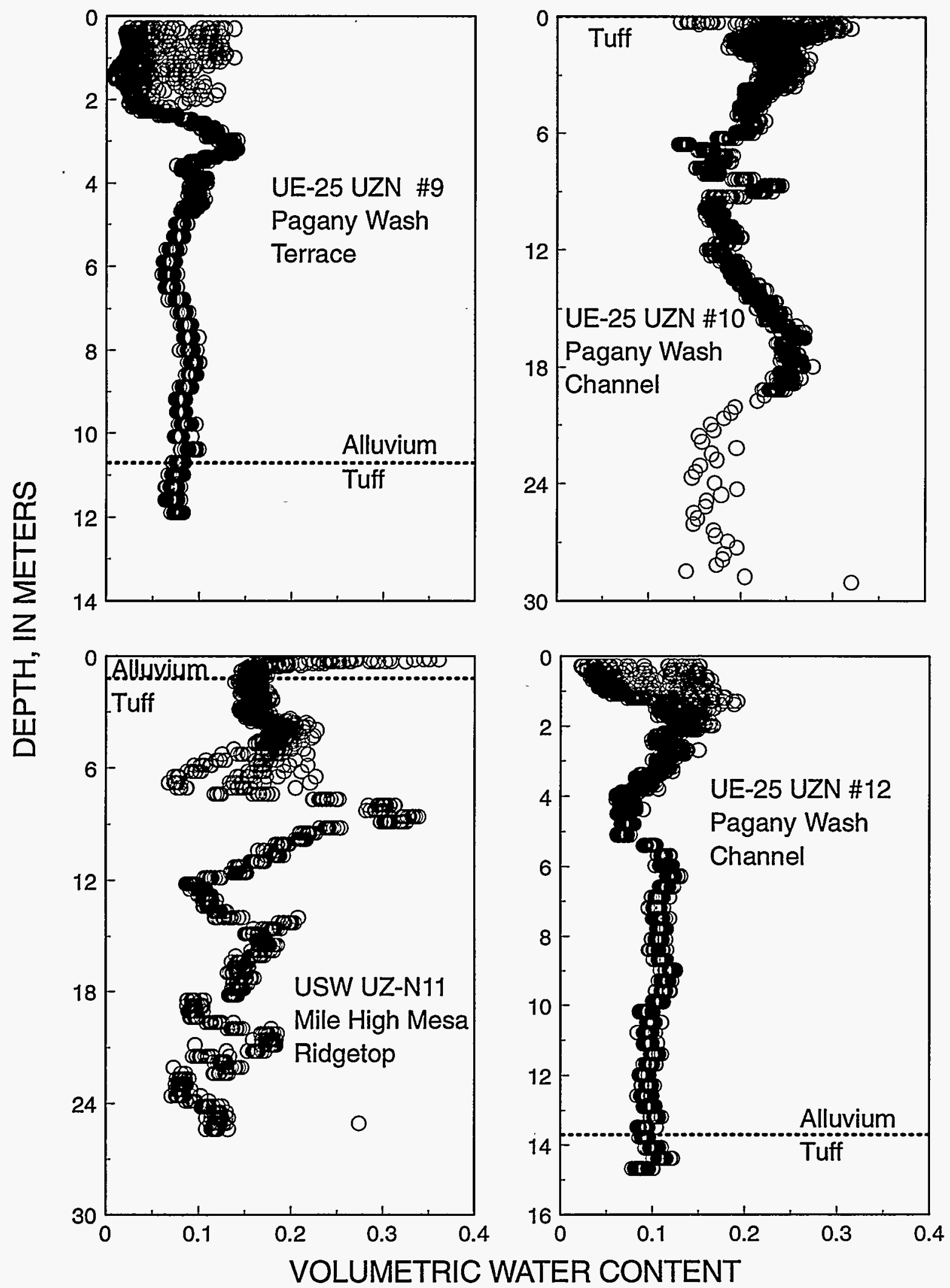

Figures 12-15. Volumetric water content with depth for boreholes UE-25 UZN \#5, UE-25 UZN \#6, UE-25 UZN \#7, and UE-25 UZN \#8. All points measured from 1/1/90 through 12/31/93 are shown. 


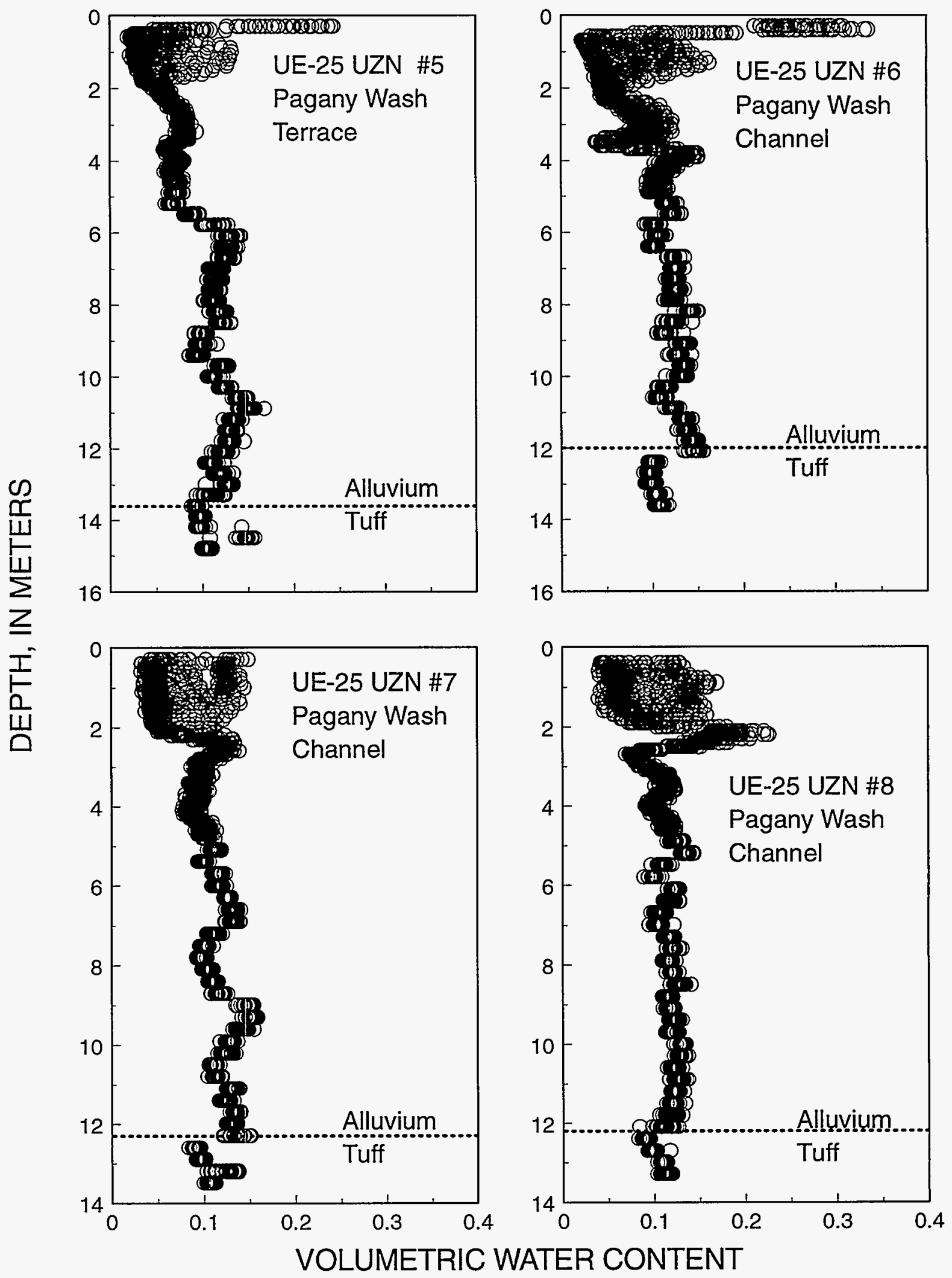

Figures 16-19. Volumetric water content with depth for boreholes UE-25 UZN \#9, UE-25 UZN \#10, USW UZ-N11, and UE-25 UZN \#12. All points measured from 1/1/90 through 12/31/93 are shown. 


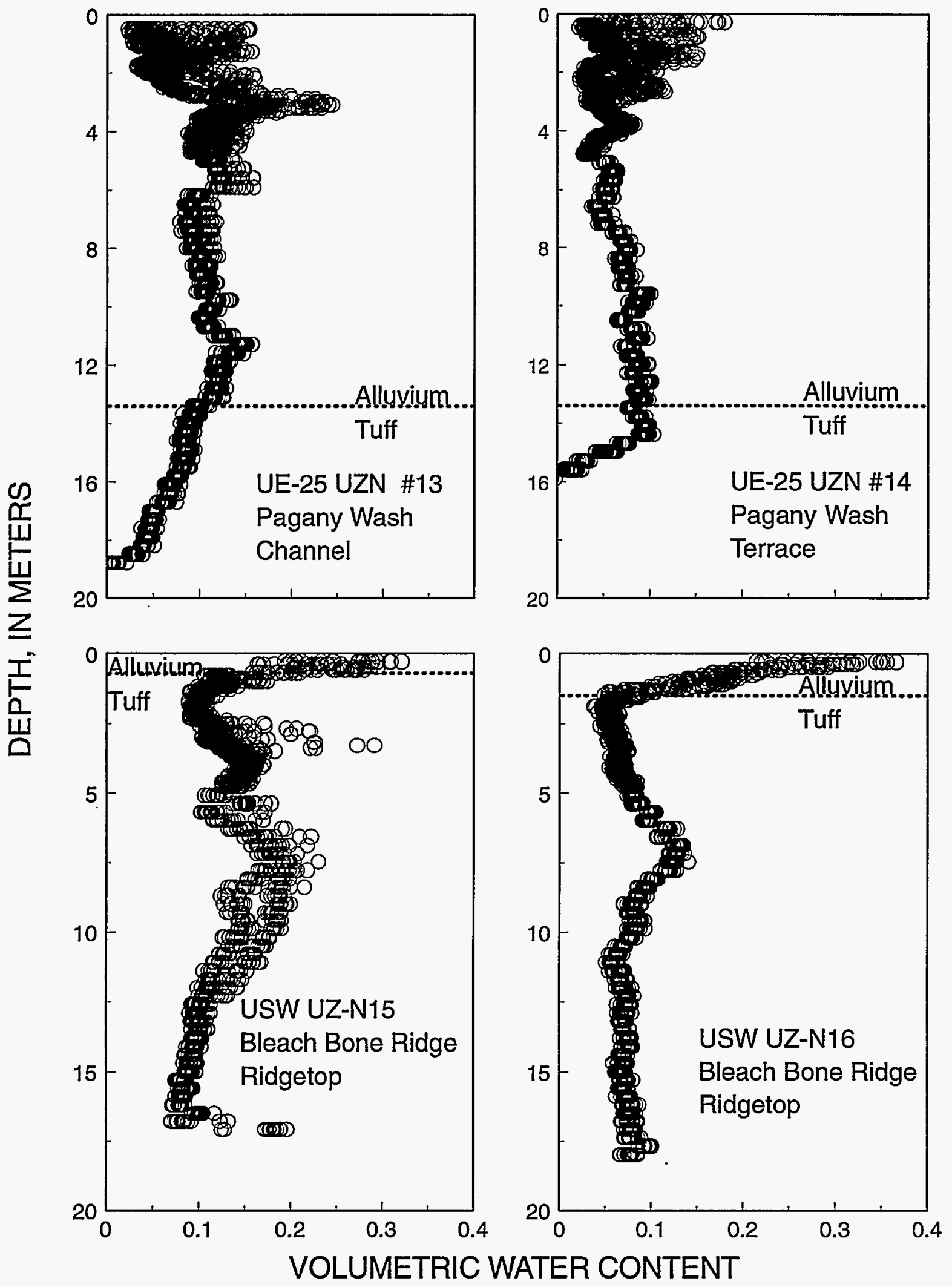

Figures 20-23. Volumetric water content with depth for boreholes UE-25 UZN \#13, UE-25 UZN \#14, USW UZ-N15, and USW UZ-N16. All points measured from $1 / 1 / 90$ through 12/31/93 are shown. 


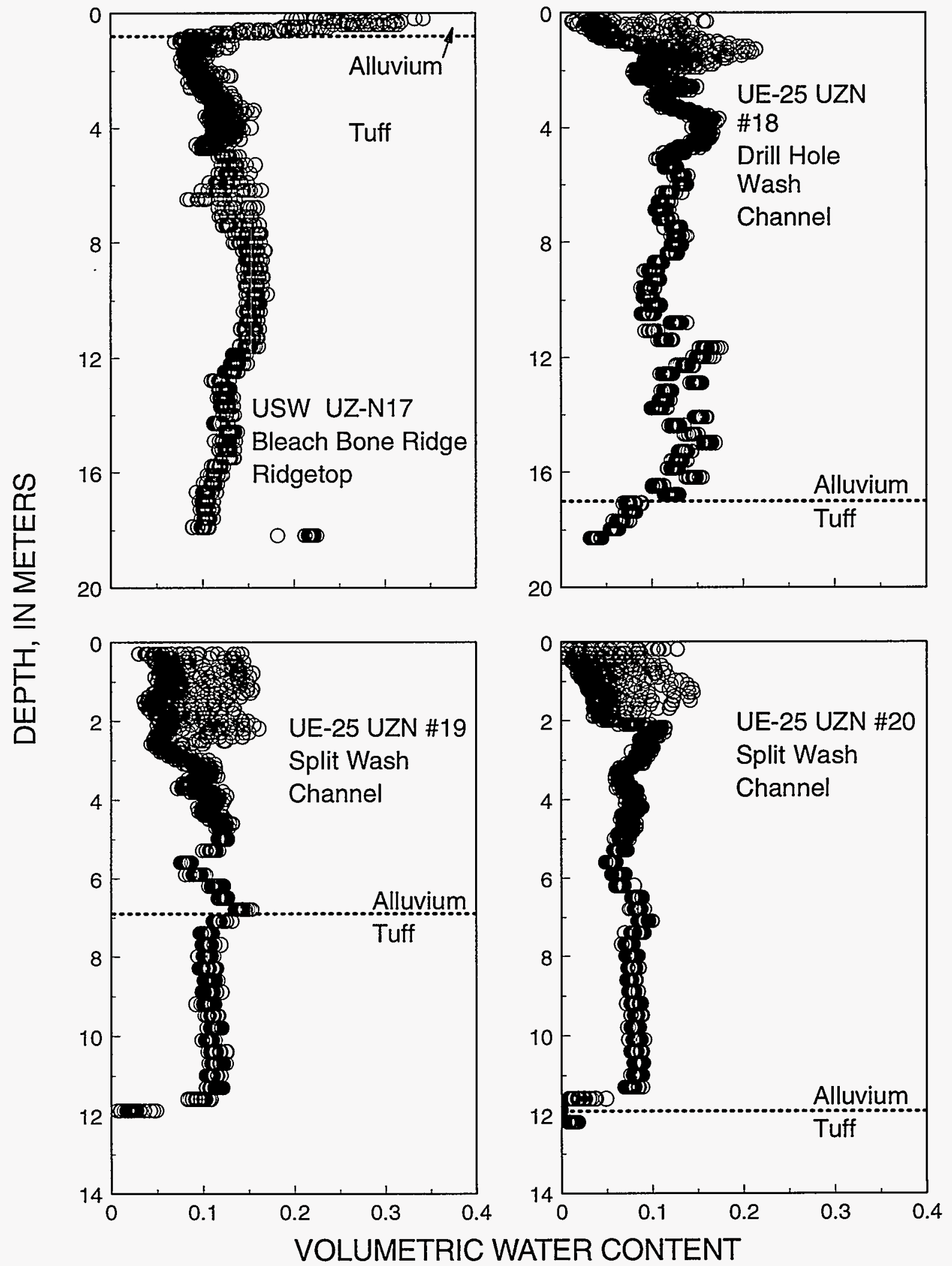

Figures 24-27. Volumetric water content with depth for boreholes USW UZ-N17, UE-25 UZN \#18, UE-25 UZN \#19, and UE-25 UZN \#20. All points measured from 1/1/90 through 12/31/93 are shown. 


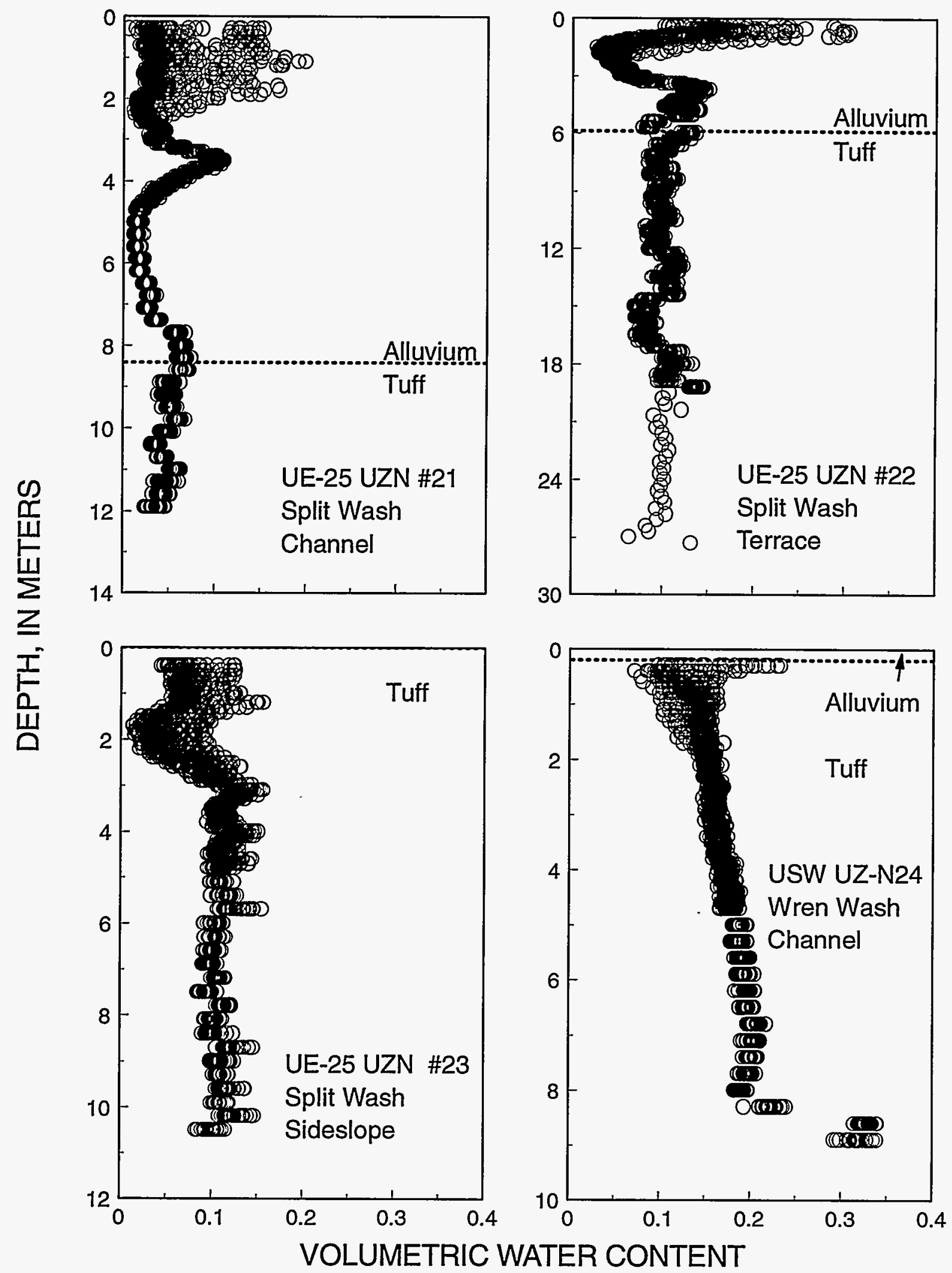

Figures 28-31. Volumetric water content with depth for boreholes UE-25 UZN \#21, UE-25 UZN \#22, UE-25 UZN \#23, and USW UZ-N24. All points measured from 1/1/90 through 12/31/93 are shown. 


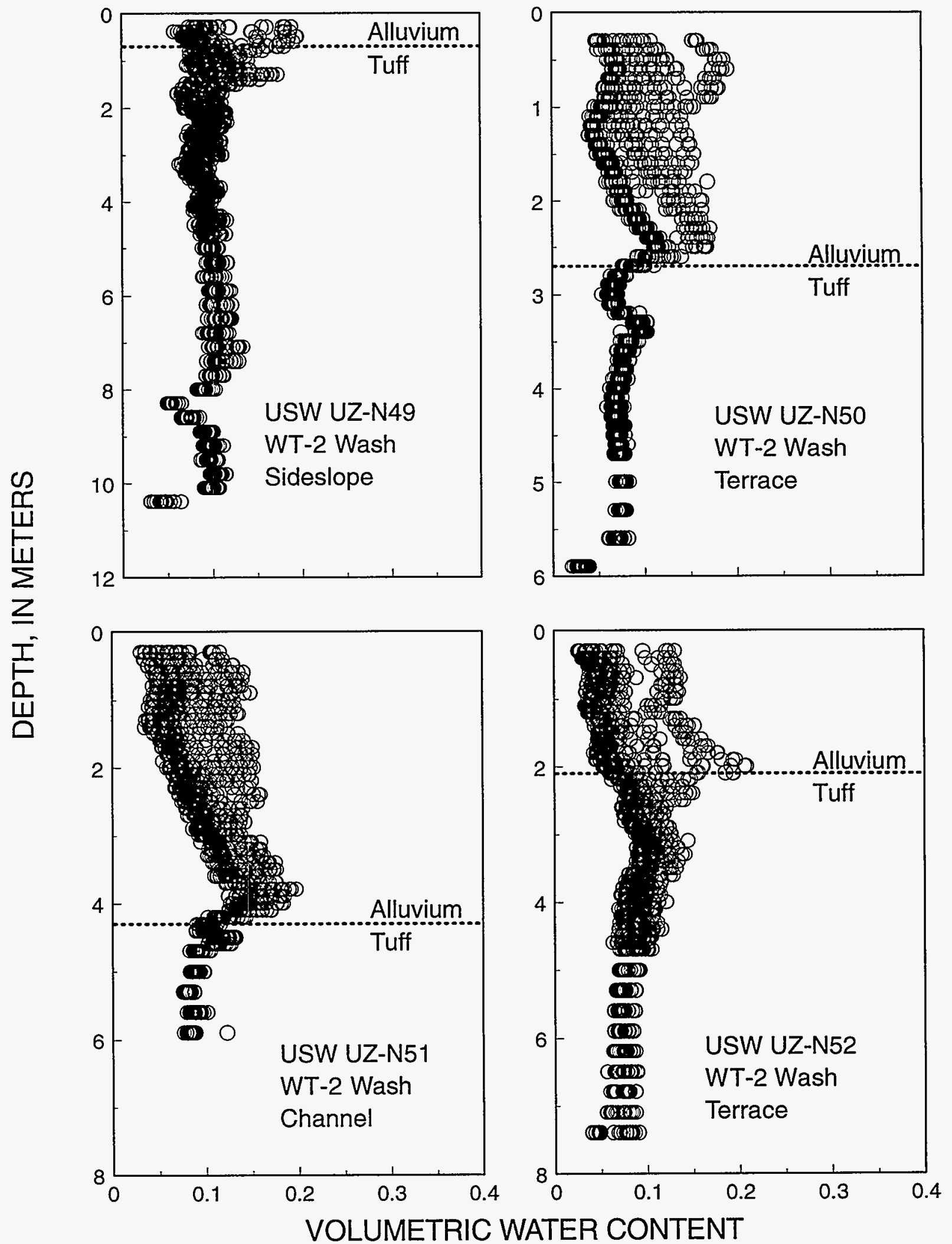

Figures 32-35. Volumetric water content with depth for boreholes USW UZ-N25, USW UZ-26, USW UZ-N27, and UE-25 UZN \#28. All points measured from $1 / 1 / 90$ through $12 / 31 / 93$ are shown. 


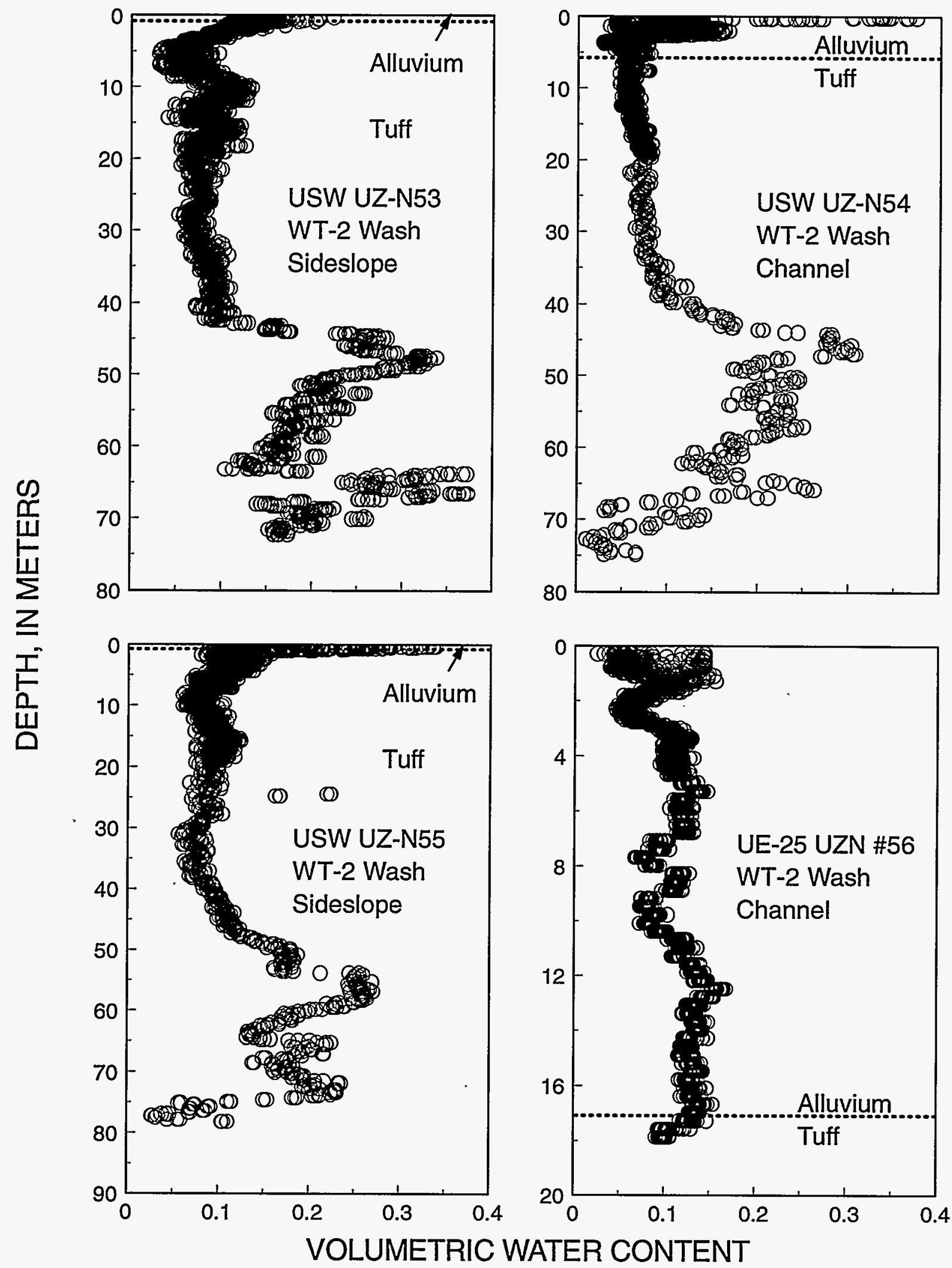

Flgures 36-39. Volumetric water content with depth for boreholes UE-25 UZN \#29, UE-25 UZN \#30, USW UZ-N31, and USW UZ-N32. All points measured from 1/1/90 through 12/31/93 are shown. 


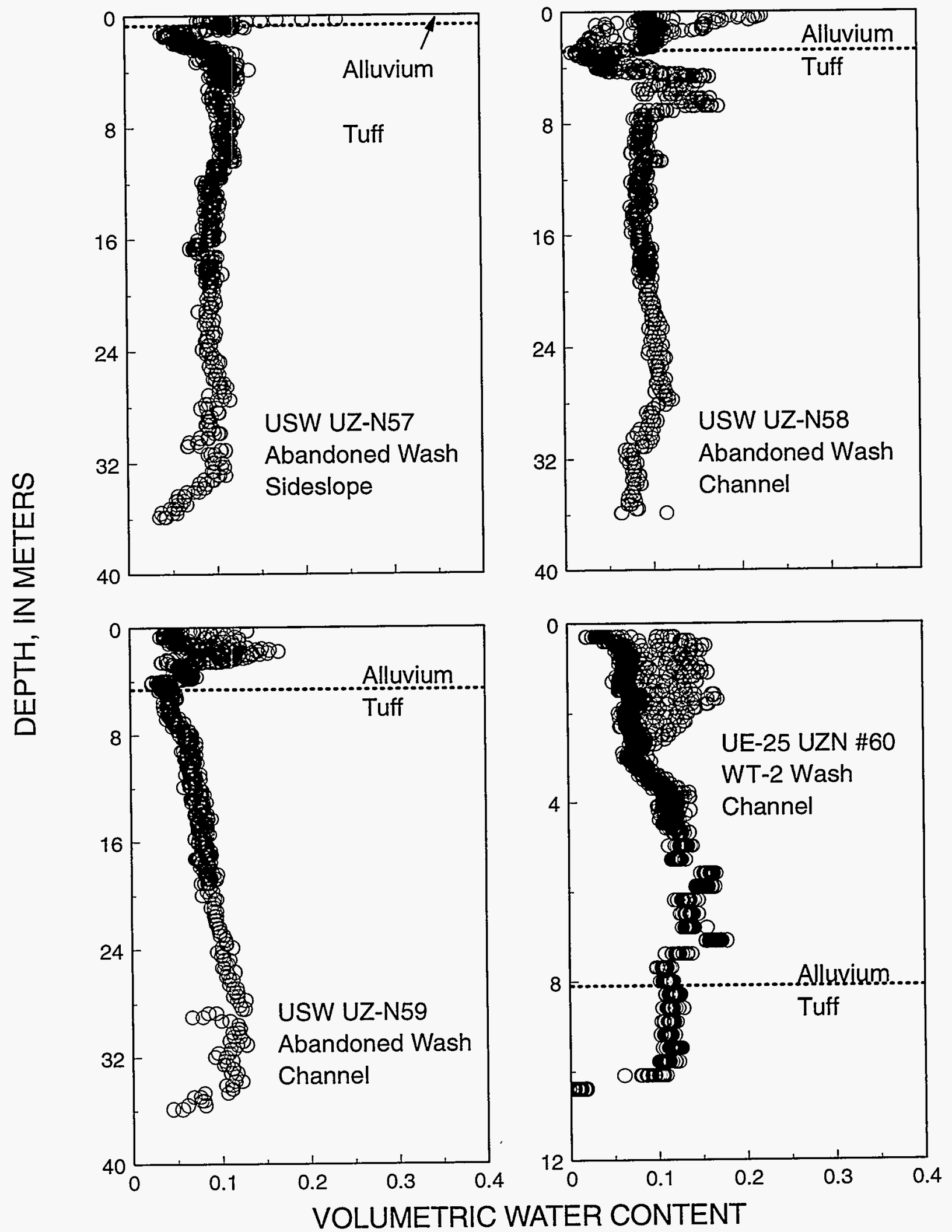

Figures 40-43. Volumetric water content with depth for boreholes USW UZ-N33, USW UZ-N34, USW UZ-N35, and USW UZ-N36. All points measured from 1/1/90 through 12/31/93 are shown. 


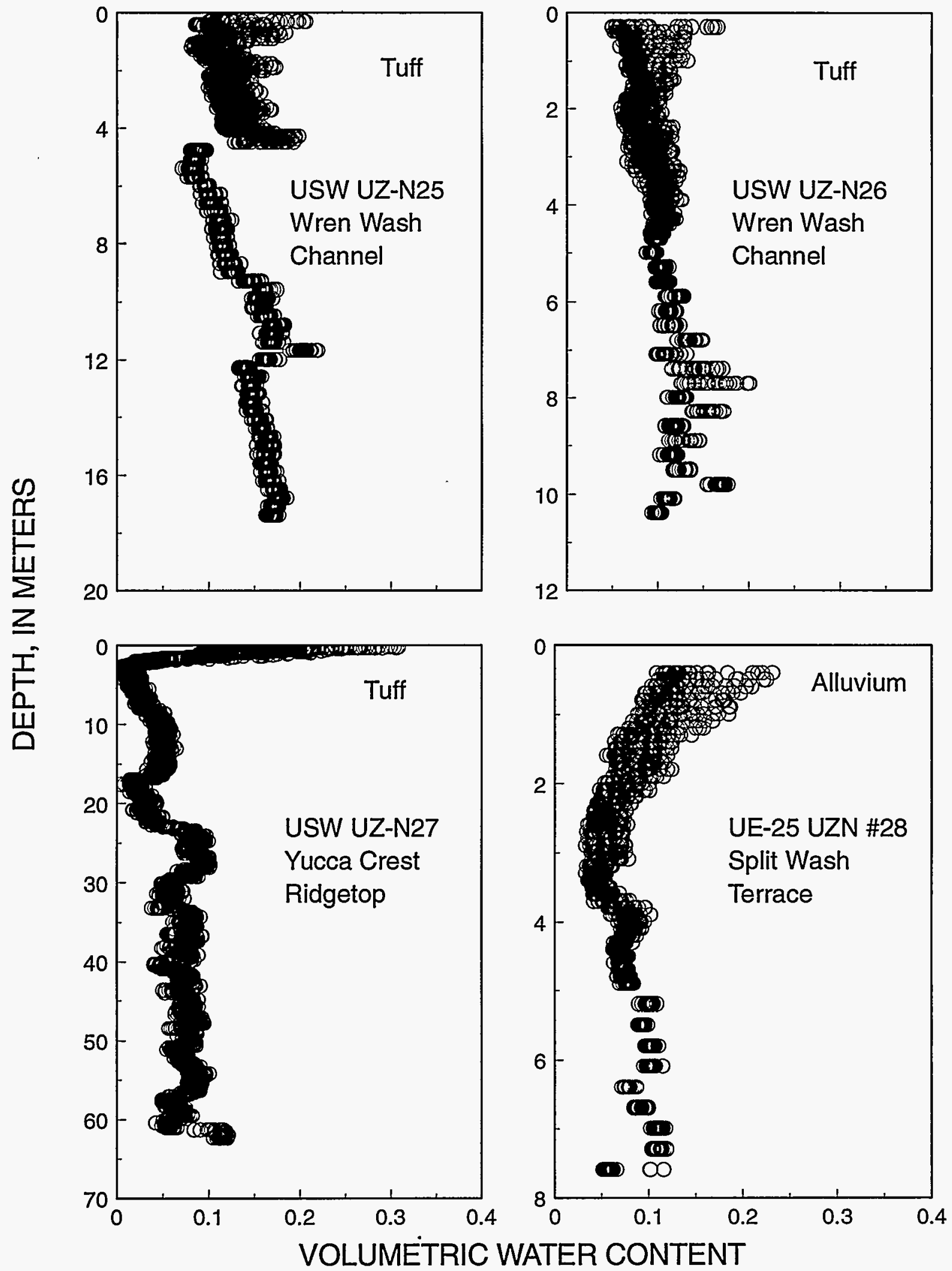

Figures 44-47. Volumetric water content with depth for boreholes USW UZ-N37, USW UZ-N38, UE-25 UZN \#39, and USW UZ-N40. All points measured from 1/1/90 through 12/31/93 are shown. 


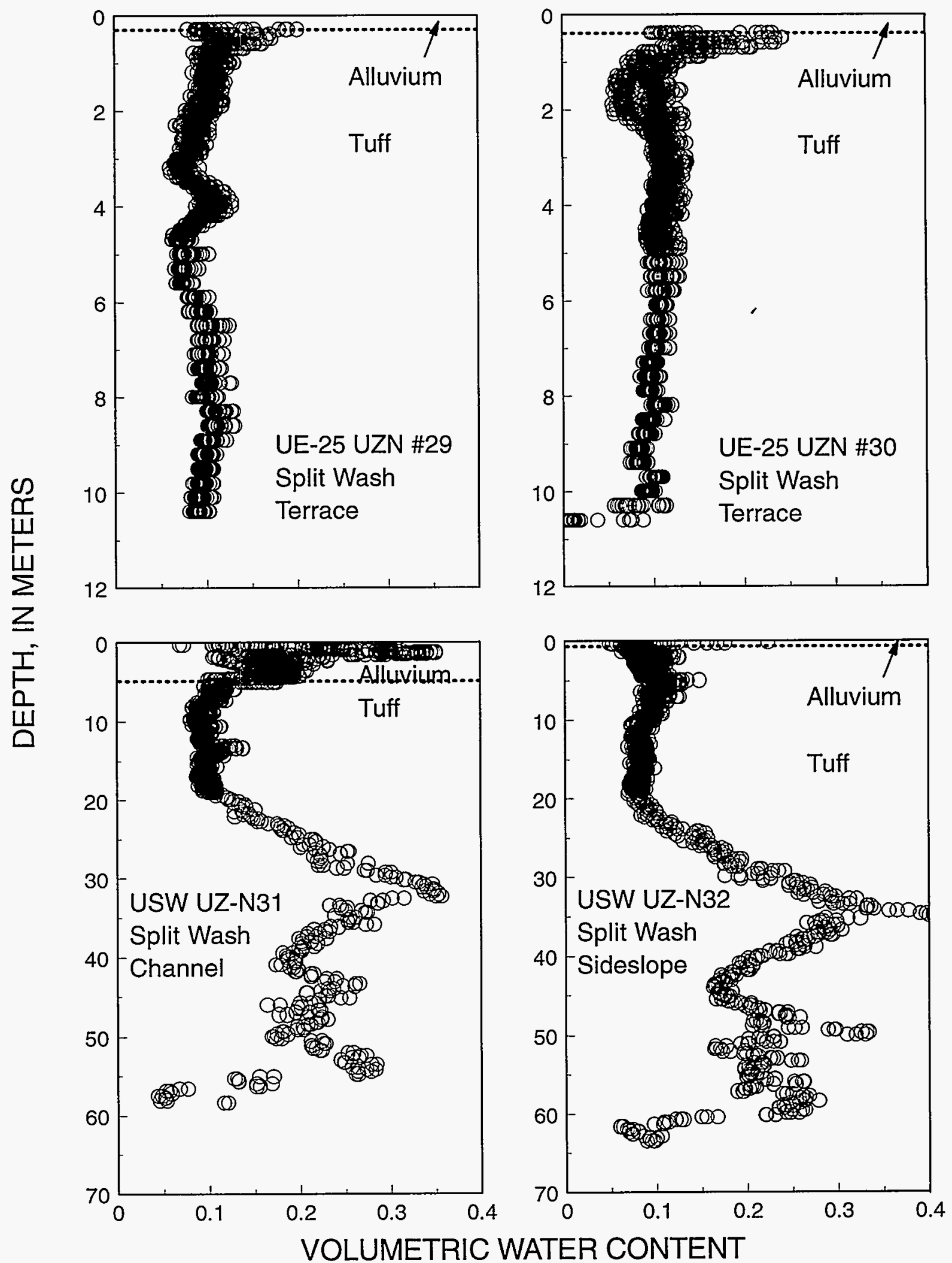

Figures 48-51. Volumetric water content with depth for boreholes USW UZ-N41, USW UZ-N42, USW UZ-N43, and USW UZ-N44. All points measured from $1 / 1 / 90$ through $12 / 31 / 93$ are shown. 


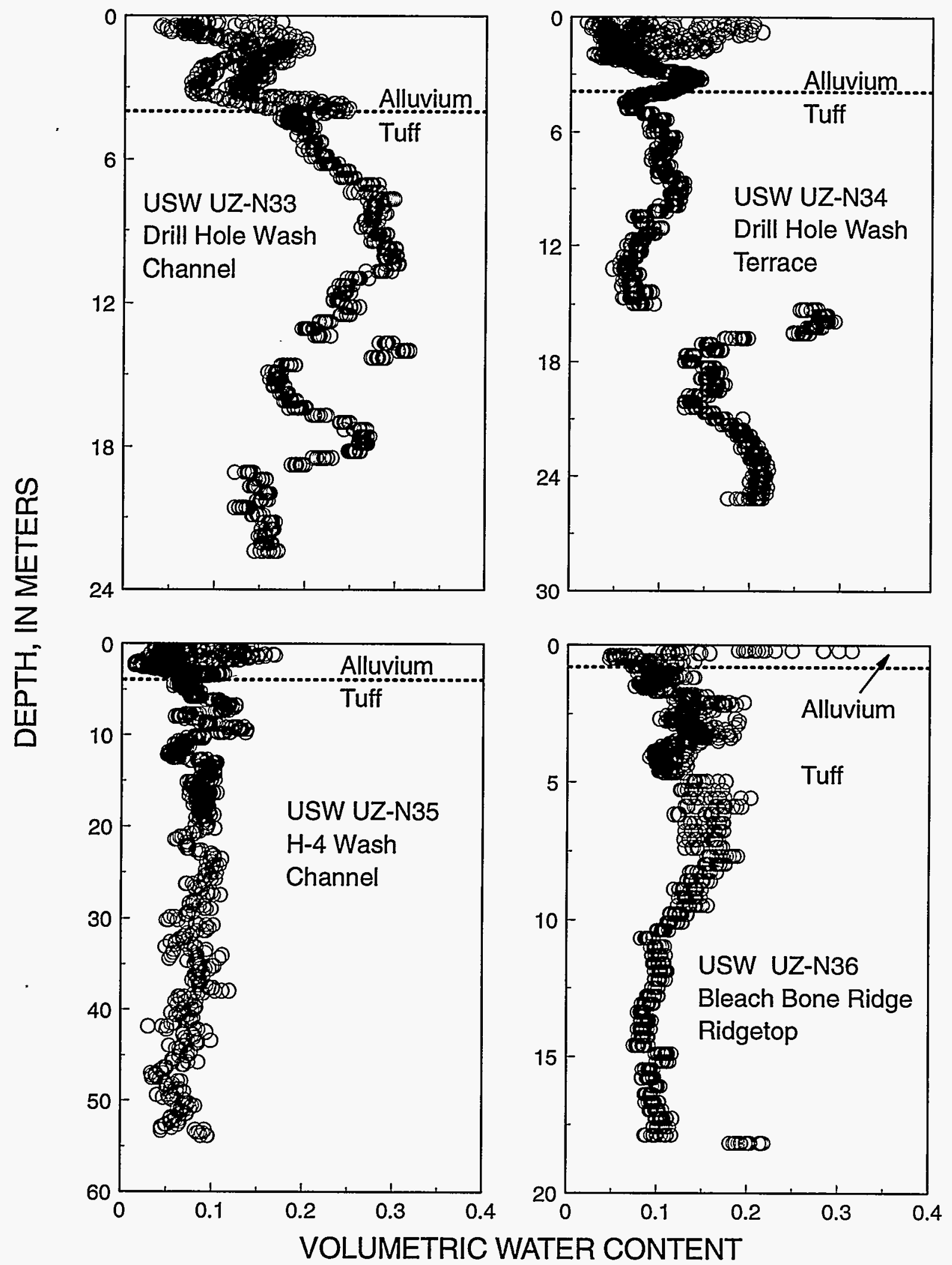

Figures 52-55. Volumetric water content with depth for boreholes USW UZ-N45, USW UZ-N46, USW UZ-N47, and USW UZ-N48. All points measured from $1 / 1 / 90$ through $12 / 31 / 93$ are shown. 


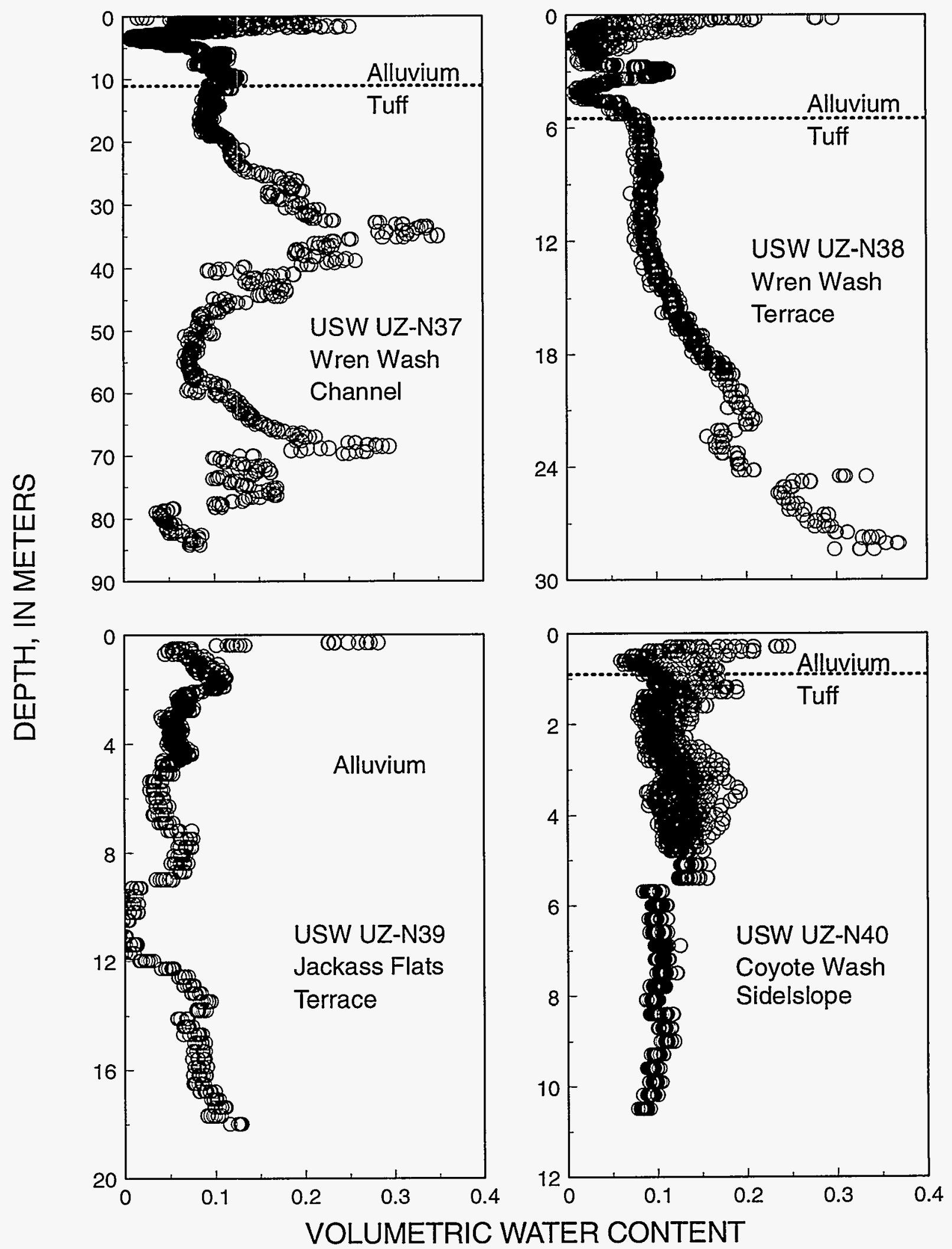

Figures 56-59. Volumetric water content with depth for boreholes USW UZ-N49, USW UZ-N50, USW UZ-N51, and USW UZ-N52. All points measured from $1 / 1 / 90$ through 12/31/93 are shown. 


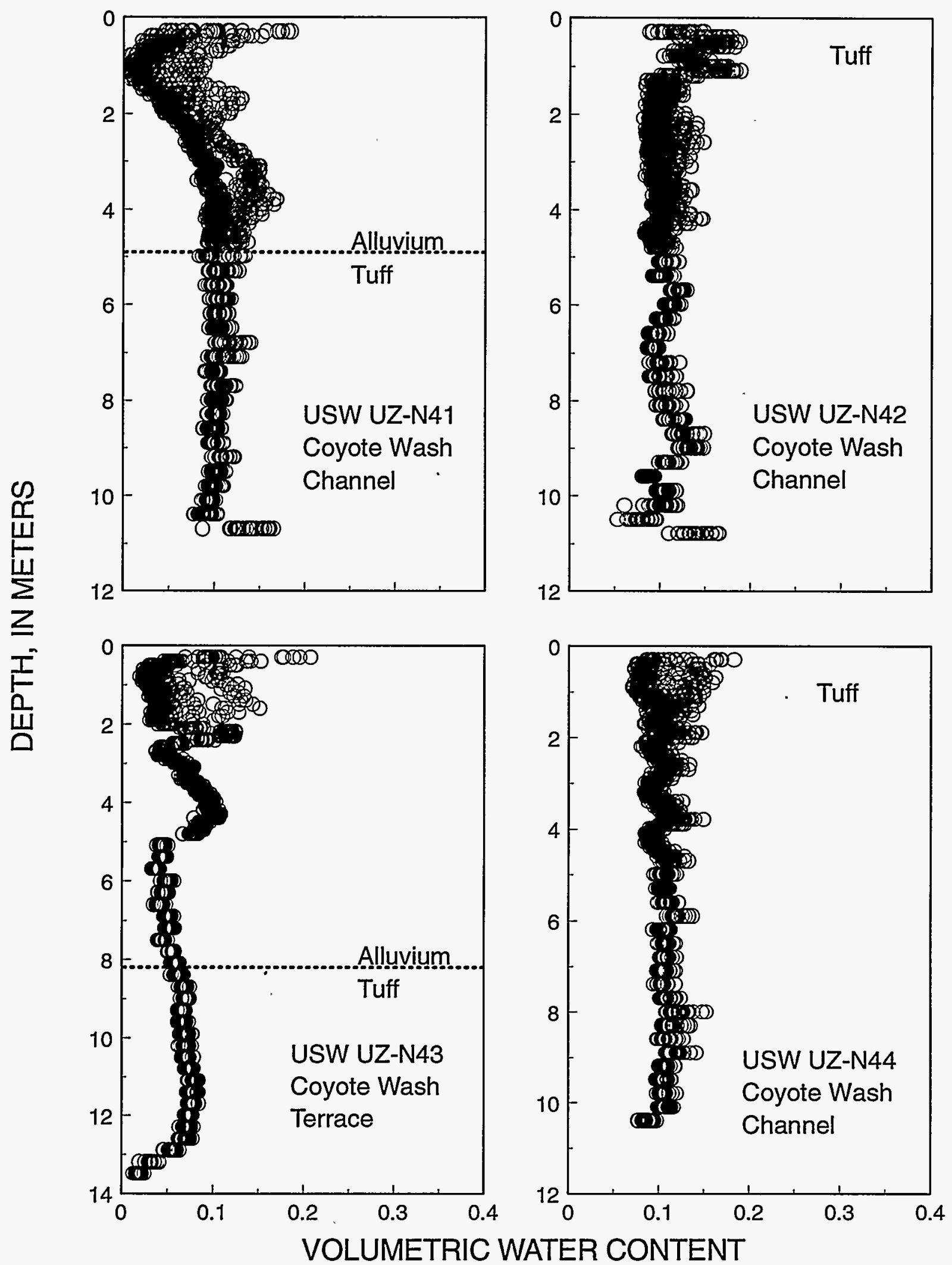

Figures 60-63. Volumetric water content with depth for boreholes USW UZ-N53, USW UZ-N54, USW UZ-N55, and UE-25 UZN \#56. All points measured from 1/1/90 through 12/31/93 are shown. 


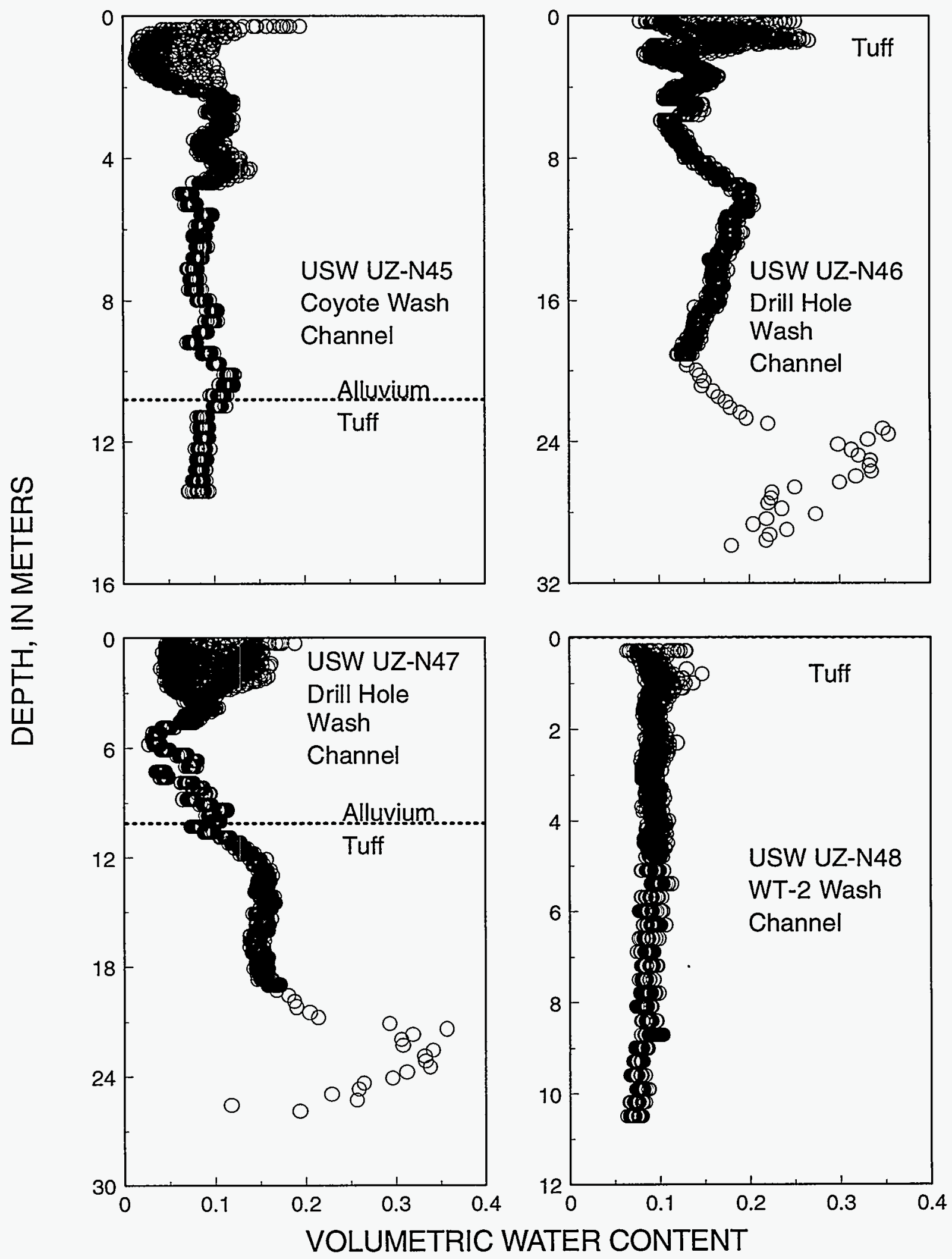

Figures 64-67. Volumetric water content with depth for boreholes USW UZ-N57, USW UZ-N58, USW UZ-N59, and UE-25 UZN \#60. All points measured from 1/1/90 through 12/31/93 are shown. 


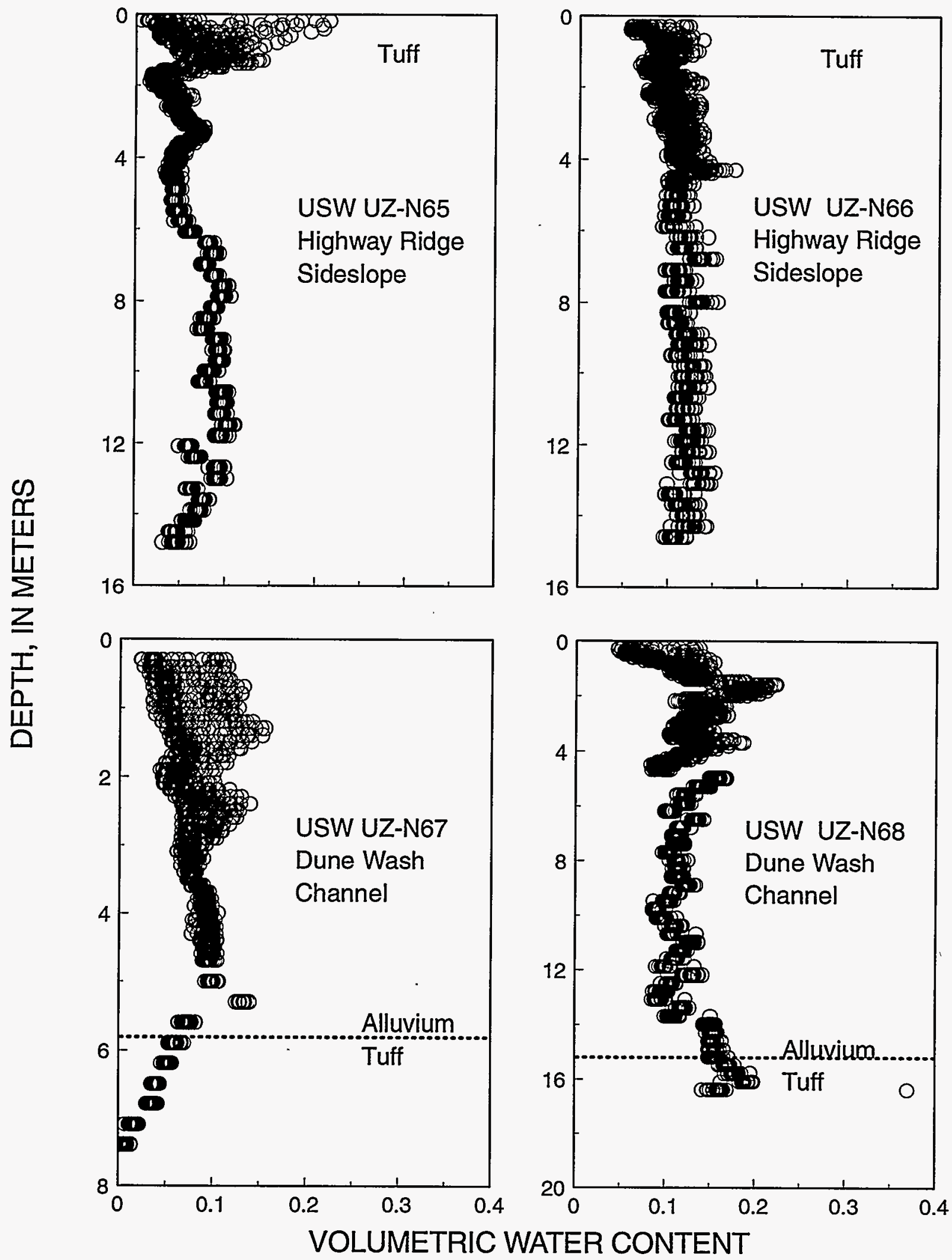

Figures 68-71. Volumetric water content with depth for boreholes USW UZ-N61, USW UZ-N62, UE-25 UZN \#63, and USW UZ-N64. All points measured from 1/1/90 through 12/31/93 are shown. 


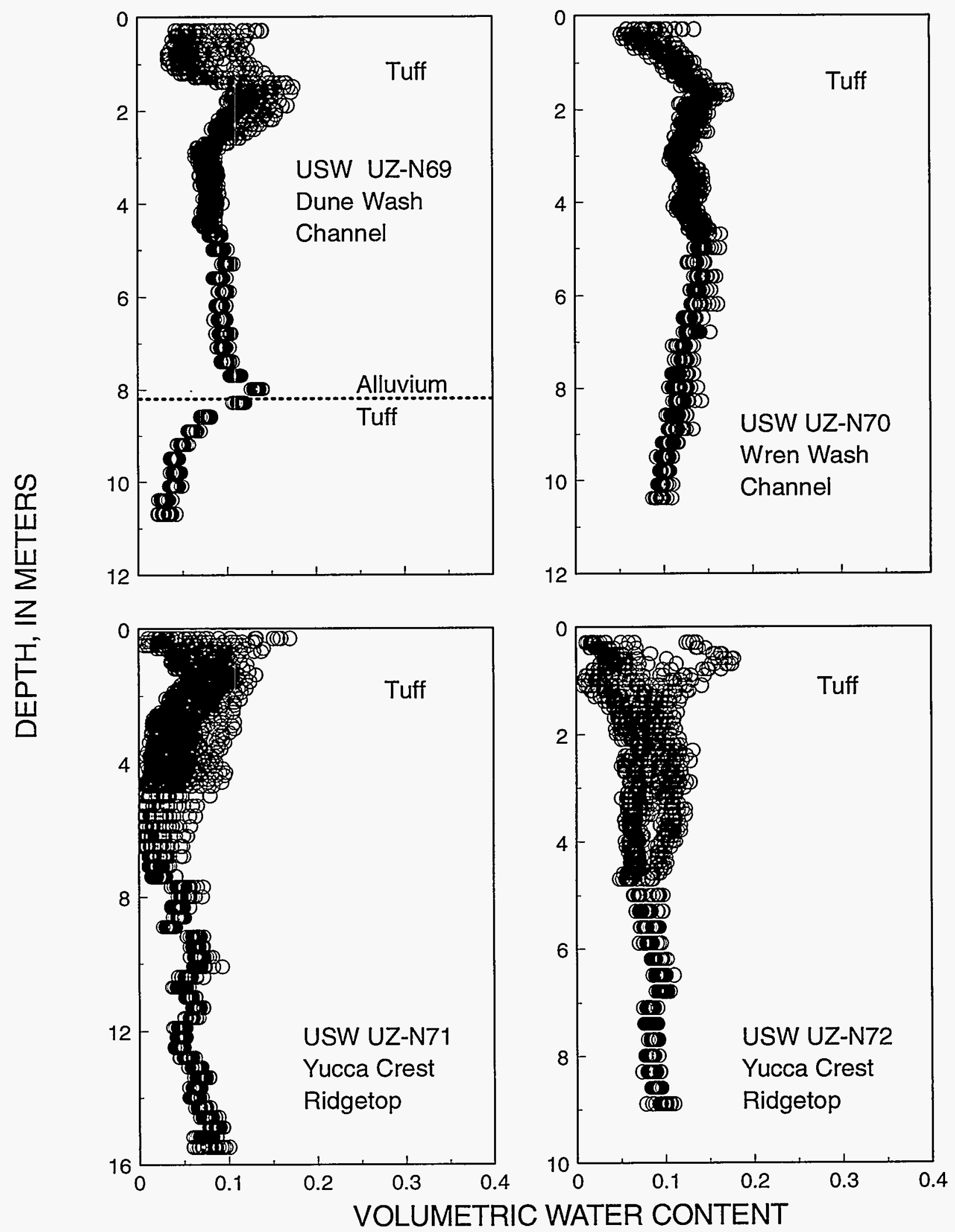

Figures 72-75. Volumetric water content with depth for boreholes USW UZ-N65, USW UZ-N66, USW UZ-N67, and USW UZ-N68. All points measured from 1/1/90 through 12/31/93 are shown. 


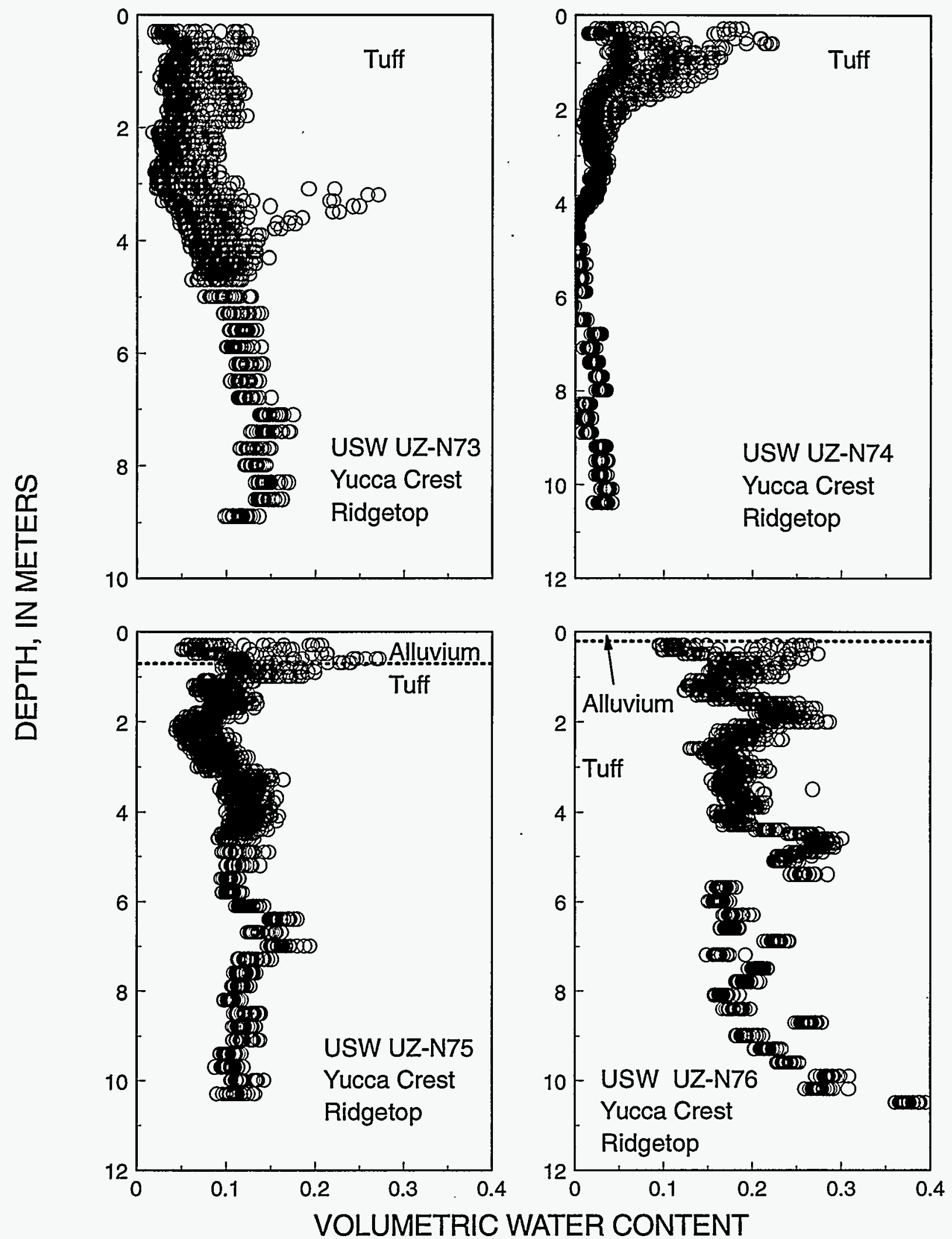

Figures 76-79. Volumetric water content with depth for boreholes USW UZ-N69, USW UZ-N70, USW UZ-N71, and USW UZ-N72. All points measured from $1 / 1 / 90$ through 12/31/93 are shown. 


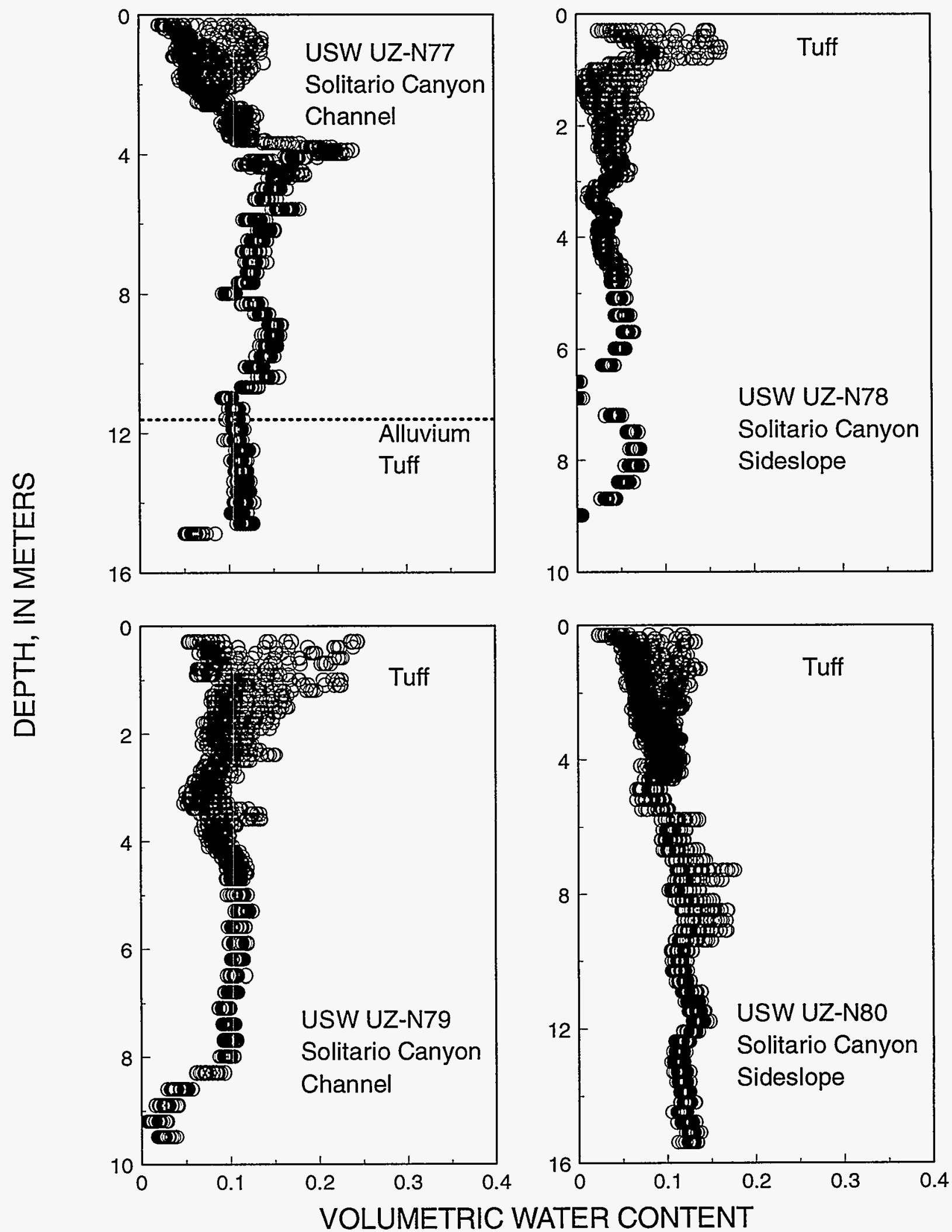

Figures 80-83. Volumetric water content with depth for boreholes USW UZ-N73, USW UZ-N74, USW UZ-N75, and USW UZ-N76. All points measured from 1/1/90 through 12/31/93 are shown. 


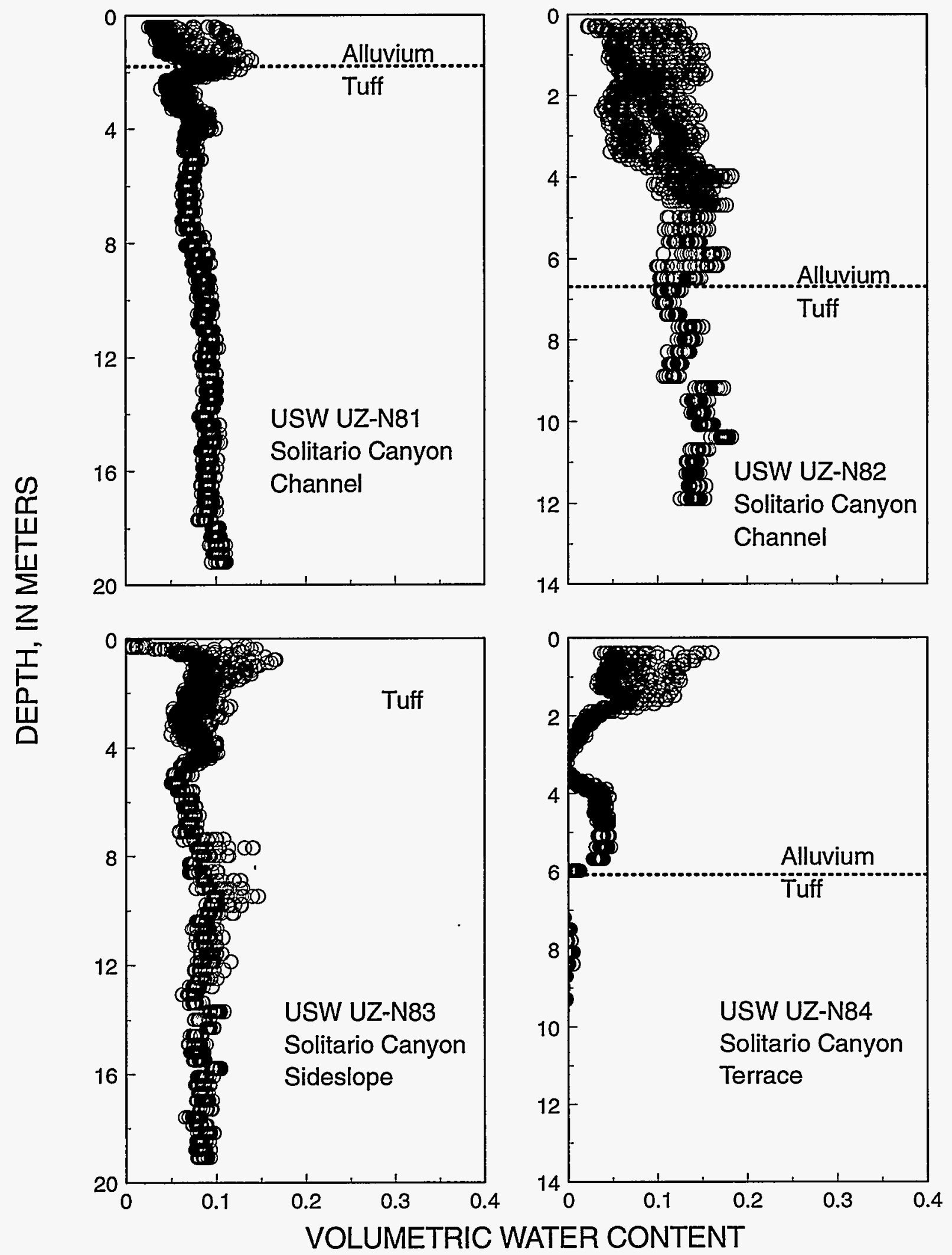

Flgures 84-87. Volumetric water content with depth for boreholes USW UZ-N77, USW UZ-N78, USW UZ-N79, and USW UZ-N80. All points measured from 1/1/90 through 12/31/93 are shown. 


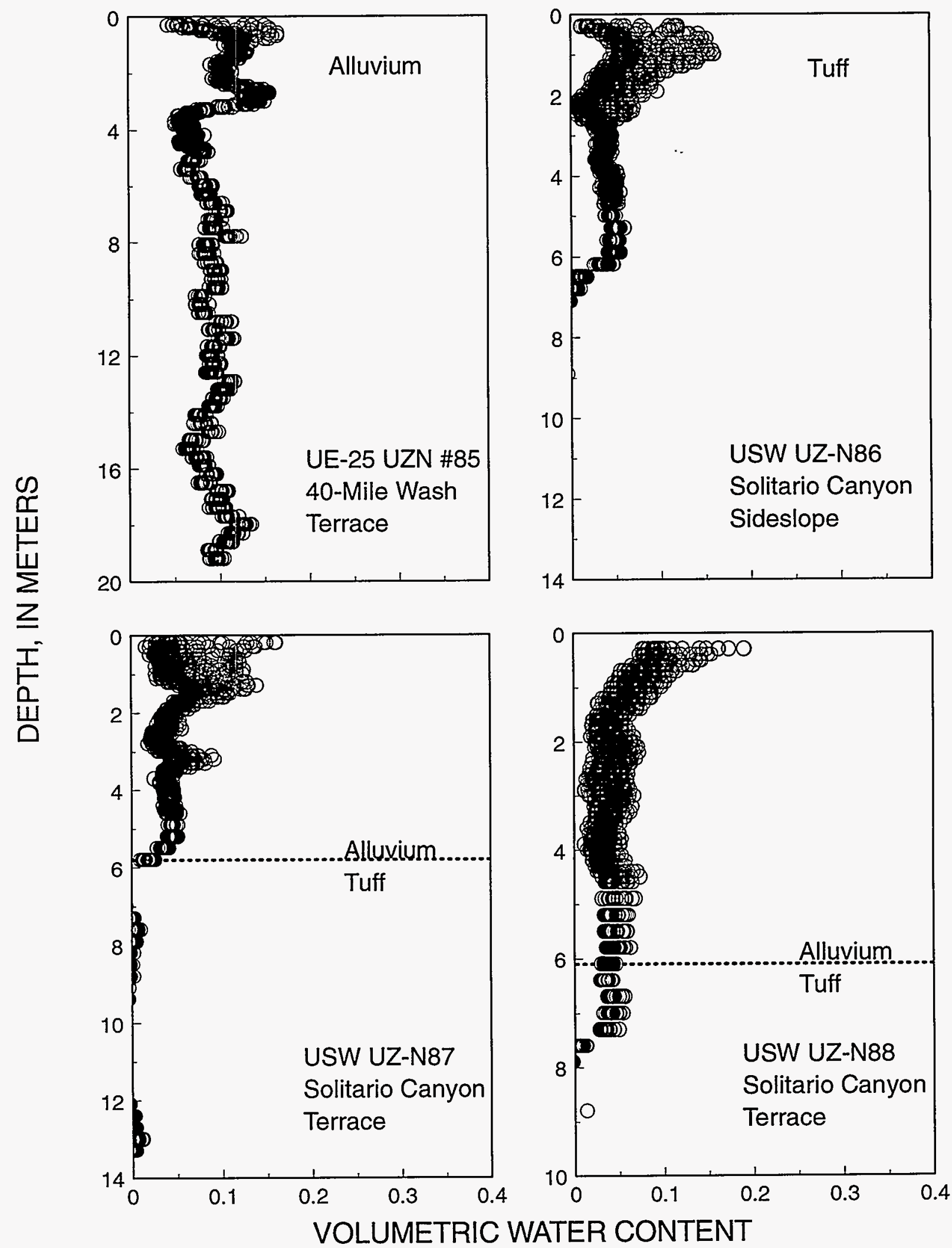

Figures 88-91. Volumetric water content with depth for boreholes USW UZ-N81, USW UZ-N82, USW UZ-N83, and USW UZ-N84. All points measured from 1/1/90 through 12/31/93 are shown. 

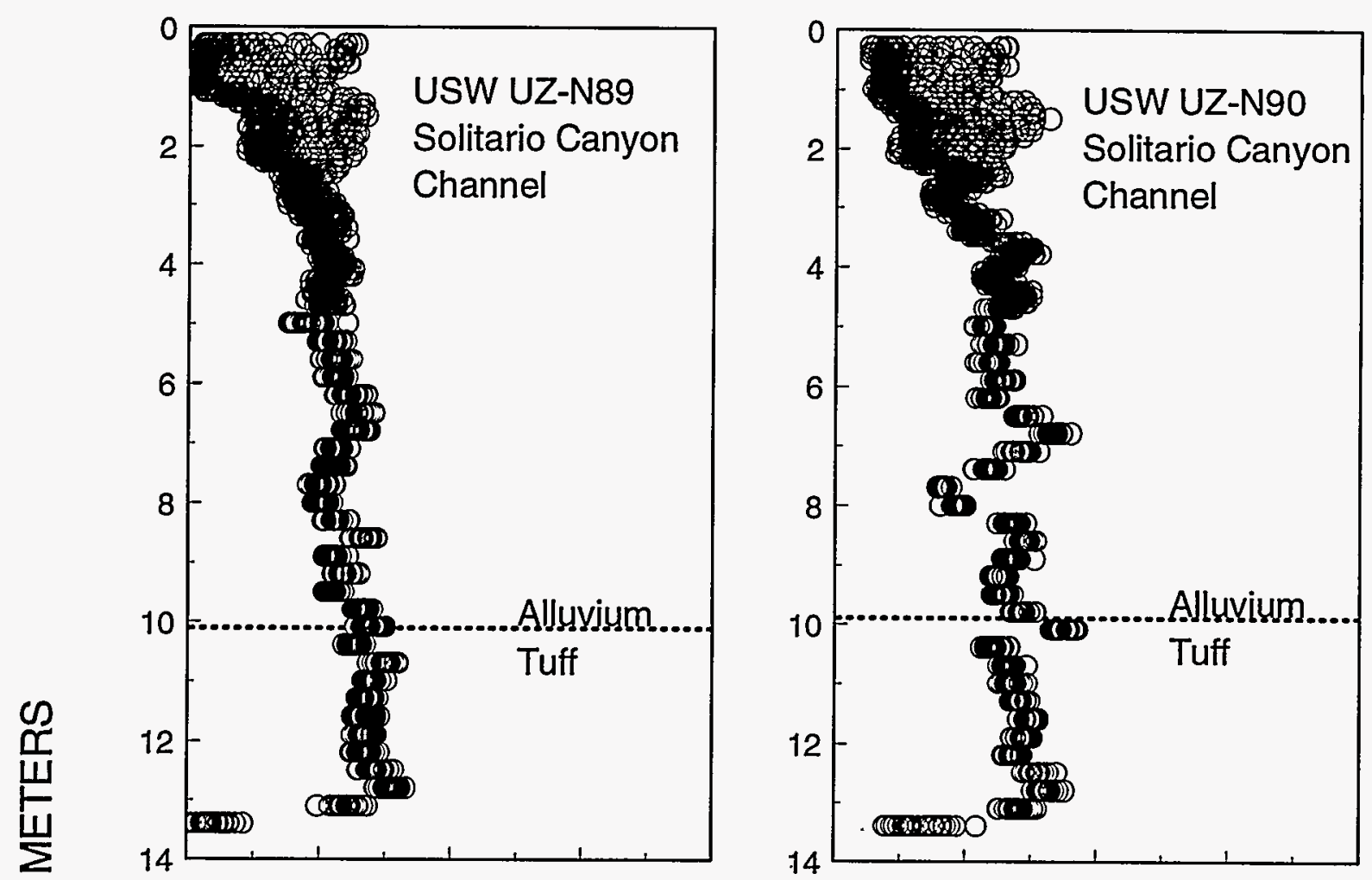

Z
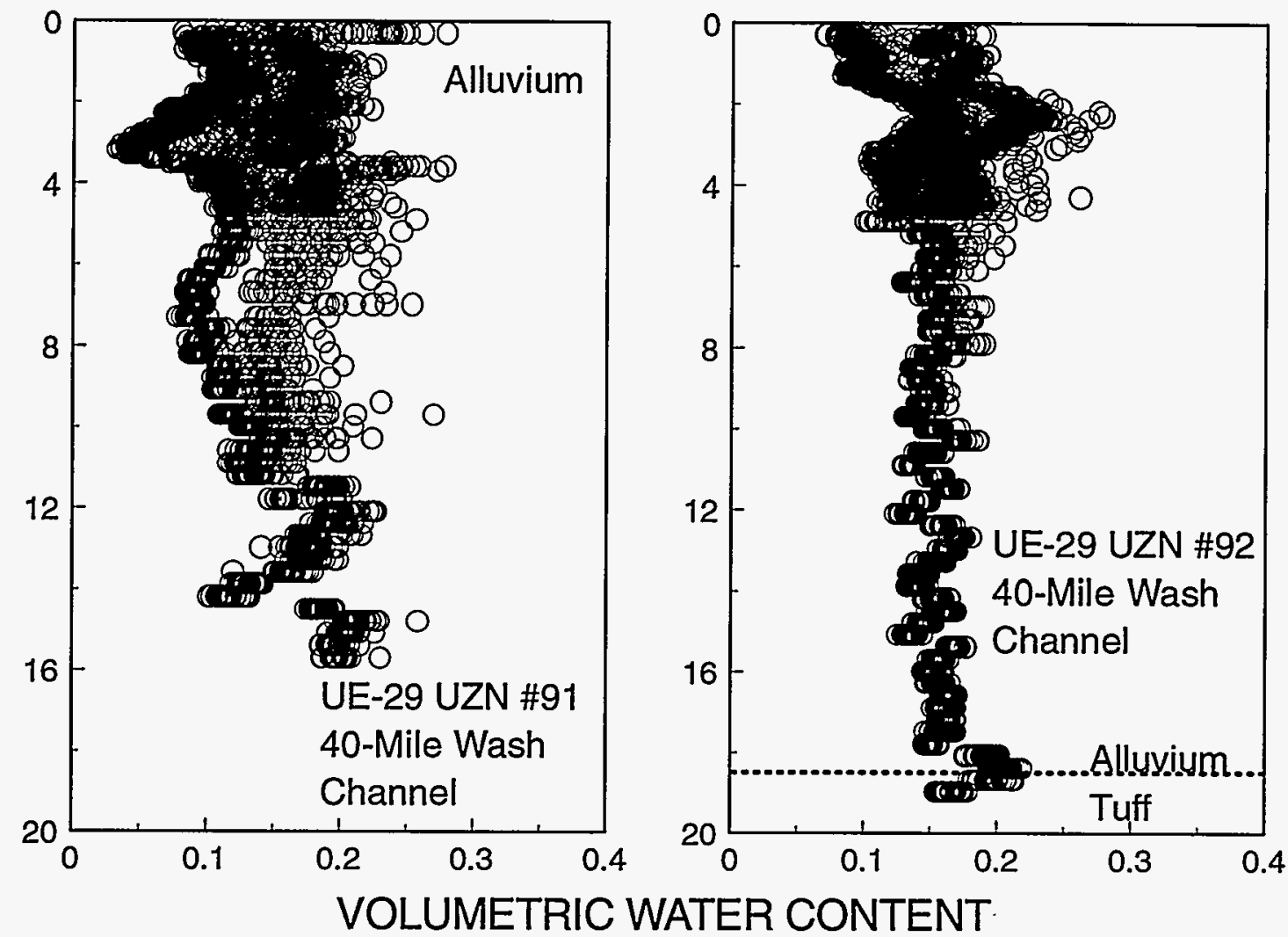

Figures 92-95. Volumetric water content with depth for boreholes UE-25 UZN \#85, USW UZ-N86, USW UZ-N87, and USW UZ-N88. All points measured from 1/1/90 through 12/31/93 are shown. 


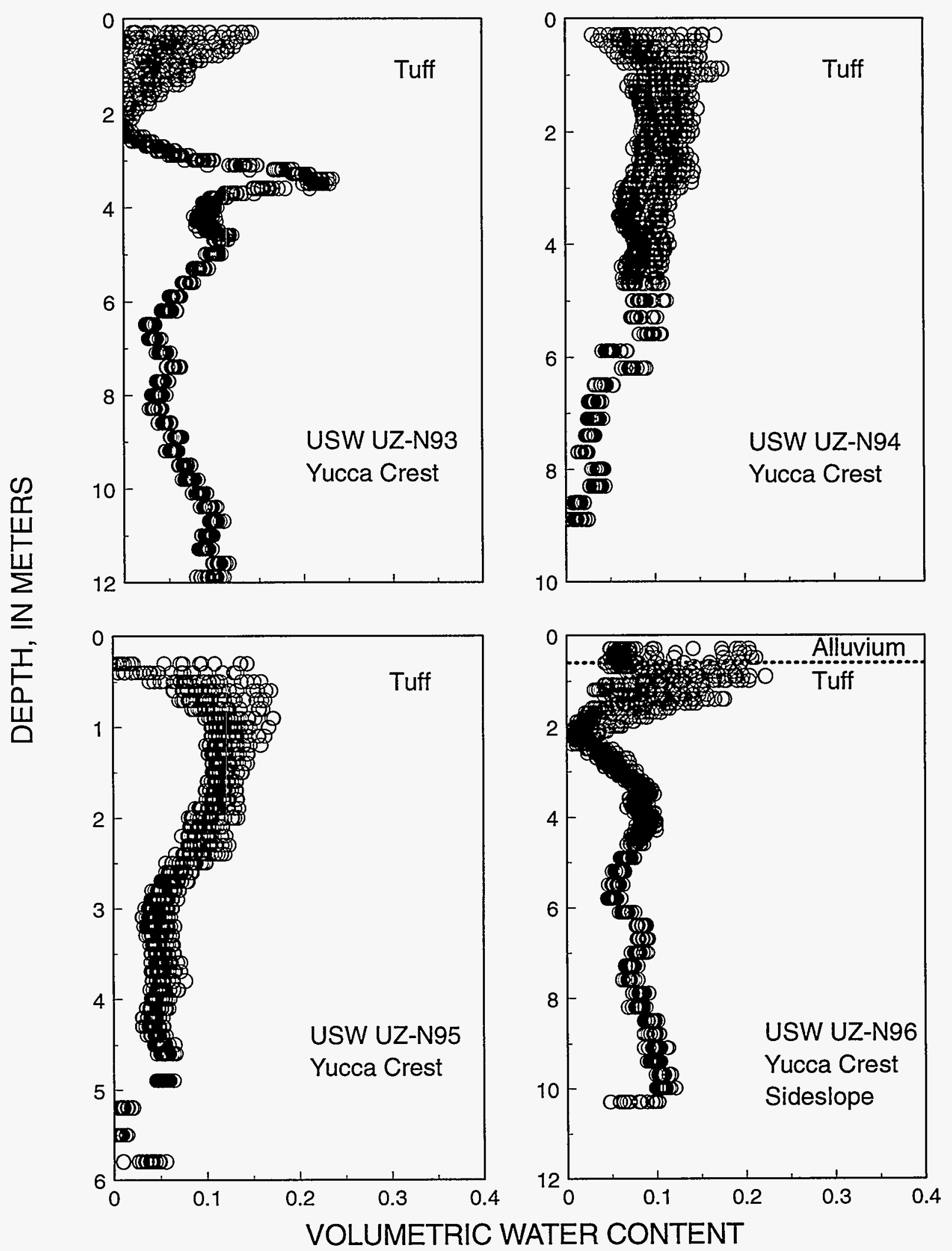

Figures 96-99. Volumetric water content with depth for boreholes USW UZ-N89, USW UZ-N90,

UE-25 UZN \#91, and UE-25 UZN \#92. All points measured from 1/1/90 through 12/31/93 are shown. 


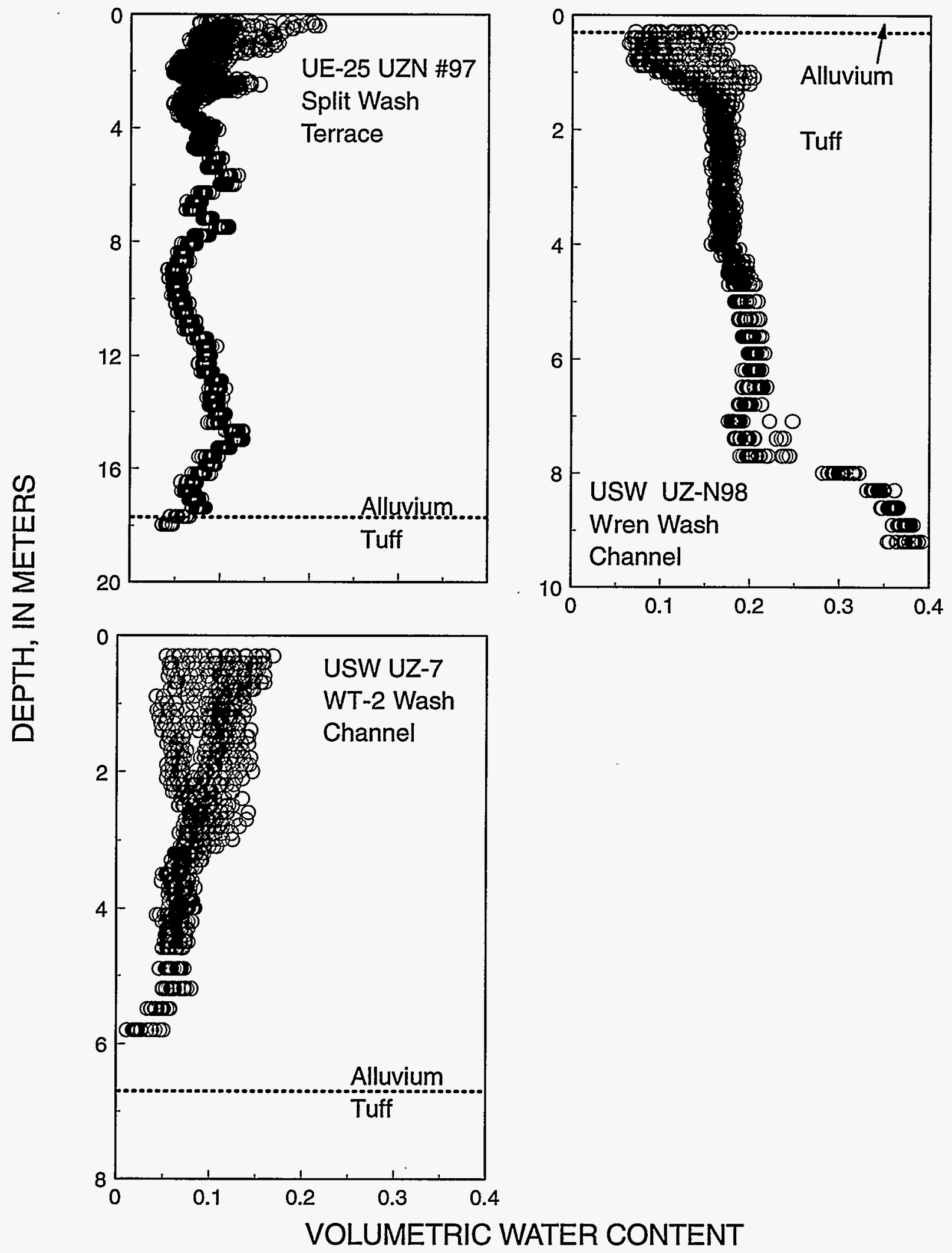

Figures 100-103. Volumetric water content with depth for boreholes USW UZ-N93, USW UZ-N94, USW UZ-N95, and USW UZ-N96. All points measured from 1/1/90 through 12/31/93 are shown. 


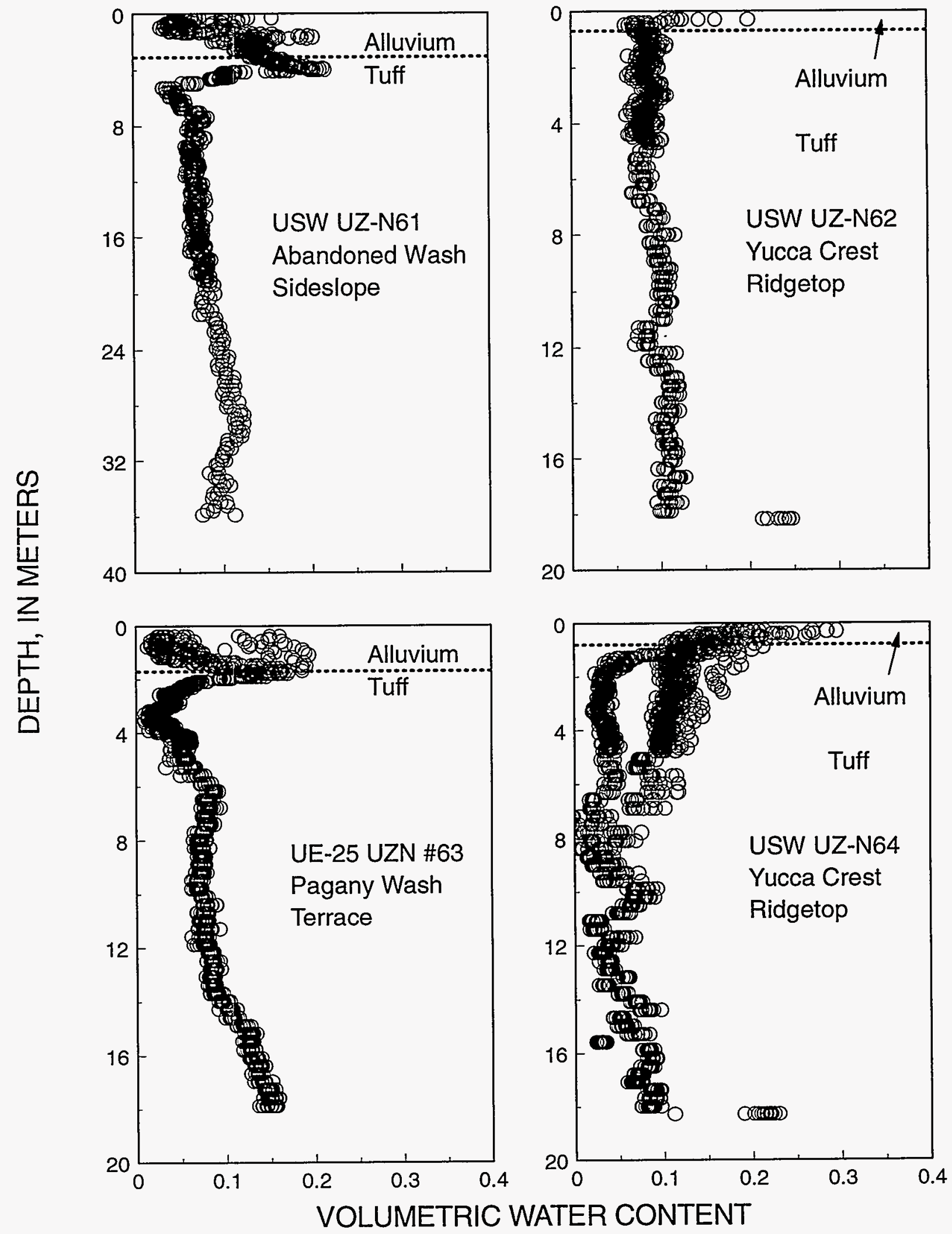

Figures 104-106. Volumetric water content with depth for boreholes USW UZ-N97, USW UZ-N98, and USW UZ-7. All points measured from 1/1/90 through 12/31/93 are shown. 